\title{
THOMPSON CHAIN
}

OF LAKES

FISHERIES

MANAGEMENT

PLAN

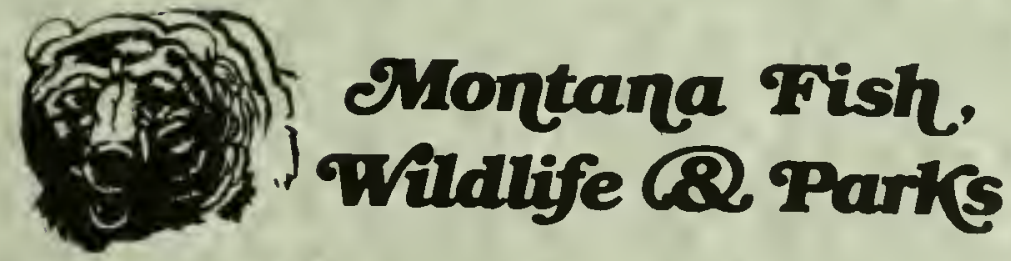

Adopted May 1997
STATE DOCUMENTS COLLECTION

JAN 252001

MONTANA STATE LIBRARY 1515 E. 6th AVE.

HEENA, MONTANA 59620 


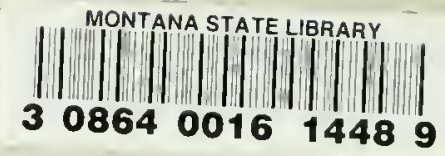




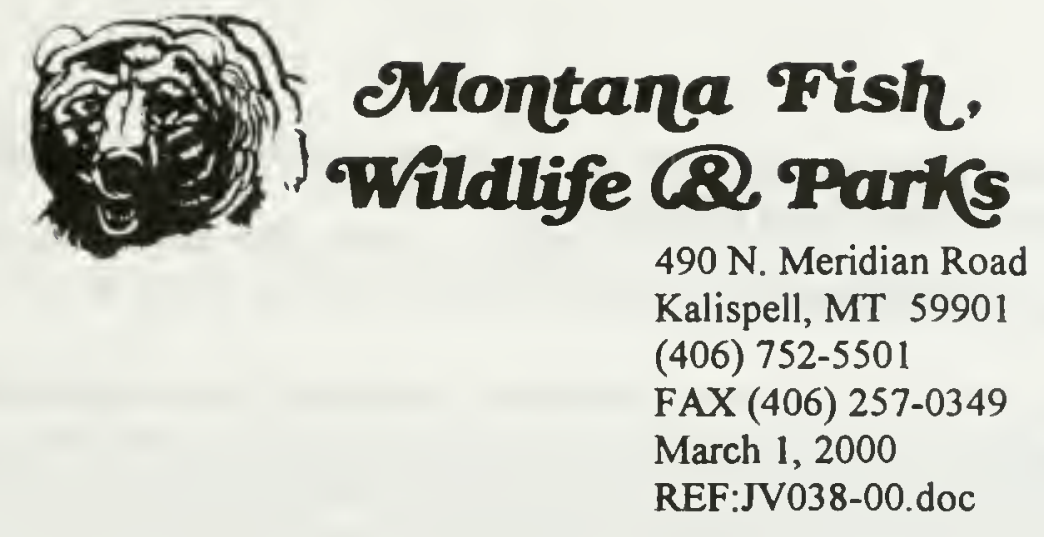

Dear Friends of the Thompson Chain of Lakes:

On May 30, 1997 the Fish, Wildlife \& Parks Commission adopted a fish management plan for TCL. Due to an oversight on our part not many copies of the plan have been distributed to the public. We're sending you the plan now so you know there's a plan guiding our management actions, because the plan provides valuable background information, and to give you an update on our progress over the last $2 \frac{1}{2}$ years.

When the Commission adopted the TCL fisheries management plan they commented on the amount of interest and support shown by TCL users. We agree and we thank you. We think we've made good progress on improving fishing in the TCL. We're always open to your questions, suggestions, and comments.

\section{McGregor Lake}

Fishing regulations were changed to make lake trout a separate 10 fish limit. The rainbow trout limit was changed to 5 trout, only 1 over 22 " in response to a greatly improved rainbow fishery that appears to be a response to changing the rainbow plant to a boat plant to scatter the fish across the lake with the help of volunteer boaters. The Boisverts site was purchased in winter, 1999 by the Fish, Wildlife \& Parks Commission to keep the site open to the public.

2. Little McGregor Lake

Little McGregor was chemically rehabilitated in 1998 to remove illegally planted bass and perch. The lake was replanted with rainbow and cutthroat with plans to replant brook trout once an environmental analysis is done. FWP is working on providing a better access.

\section{Lower Thompson Lake}

A kokanee stocking evaluation is ongoing and the kokanee limit has been lowered to 10 salmon daily in an attempt to boost salmon numbers. A good winter salmon fishery has developed. Illegally planted northern pike appear to be increasing so 
the lake will be opened to pike spearing through the ice. The bass club placed stumps for bass habitat enhancement.

4. Middle Thompson Lake

Changes the same as Lower Thompson. In addition, the kokanee stocking evaluation didn't turn up any hatchery salmon in Middle Thompson so salmon snagging was eliminated to protect the wild salmon spawners. The bass club placed some stumps in Middle Thompson for habitat enhancement.

5. Upper Thompson Lake

Pike spearing through the ice was added in 1998. Good fishing for larger perch has appeared in both Middle and Upper Thompson the last few years.

6. Rainbow Lake

Long-term public access remains as an issue.

7. Crystal and Lavon Lakes

The salmon fishing appears to be back on track after the planting program was stabilized although the salmon are small this winter for some reason. We're taking a look at rainbow stocking rates and at long-term access since Happy's Inn is up for sale.

8. Bootjack Lake

Bootjack was chemically rehabbed in 1997 and replanted with rainbow and westslope cutthroat. It is providing excellent fishing.

9. Topless Lake

Topless was rehabbed in 1998 and replanted with rainbow and westslope cutthroat. Look for it to come on this summer.

10. Cibid Lake

Cibid was rehabbed in 1997 and replanted with westslope cutthroat and rainbows.

11. Horseshoe Lake

The Environmental Assessment on introducing tiger muskies is about half done but keeps getting stalled with higher priorities such as bull trout work. 
12. Loon, Little Loon Lakes

Angling restrictions were added during bass spawning (May 15 - June 30, 1 bass daily, 22" minimum) to keep these wild populations self-sustaining.

13. Banana Lake

This lake has been reinfested with rough fish, probably during a flood of the Pleasant Valley Fisher River. We'll probably plan a rehab in the next few years to restore the trout fishery.

\section{Additional Work}

A moratorium was placed on brook trout stocking because they potentially compete and hybridize with bull trout. We'll try to complete an EA in the next year to reinitiate brook trout stocking where it's not a problem.

A land trade was completed with Plum Creek Timber to secure additional shoreline on a number of lakes. Facility developments have occurred or are planned at a number of lakes (contact Parks Division). Regulations on motorboats have been placed on a number of boats and a follow-up survey was conducted on support and compliance (contact Enforcement Division).

Sincerely,

Mike Hensler

Fisheries Biologist

(406) 293-4161

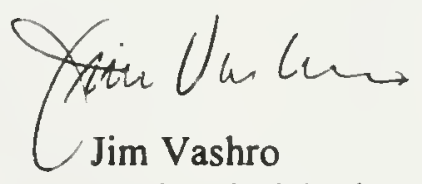

Regional Fisheries Manager (406) $751-4550$ 



\title{
THOMPSON CHAIN OF LAKES FISHERIES MANAGEMENT PLAN
}

\author{
Prepared By: \\ Mike Hensler, Fishery Biologist \\ Jim Vashro, Regional Fishery Manager \\ Montana Fish, Wildlife \& Parks \\ 490 North Meridian Road \\ Kalispell, Montana 59901
}

Adopted May 30, 1997 


\section{TABLE OF CONTENTS}

Page

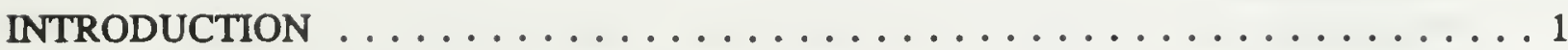

PUBLIC INVOLVEMENT PROCESS ........................ 1

SYSTEM WIDE MANAGEMENT GOALS . . . . . . . . . . . . . . . . . 5

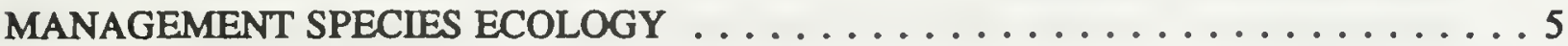

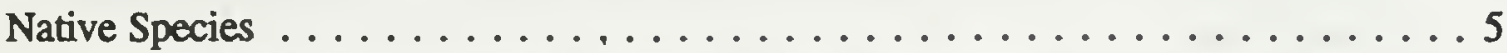

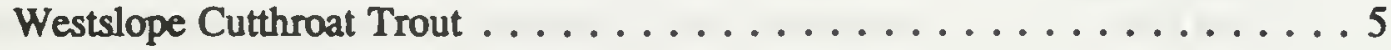

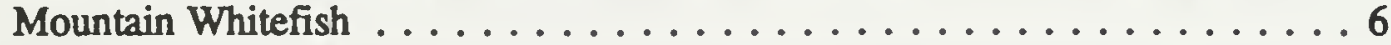

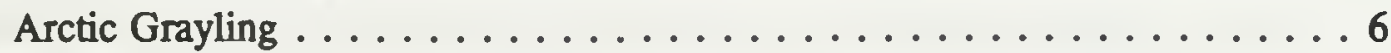

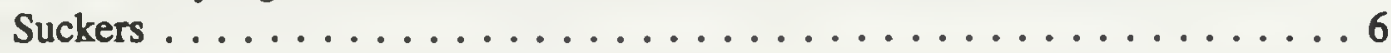

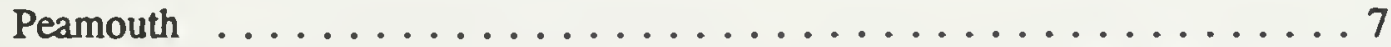

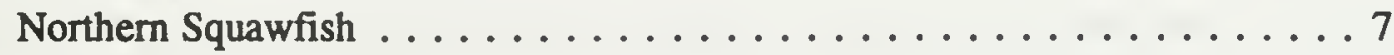

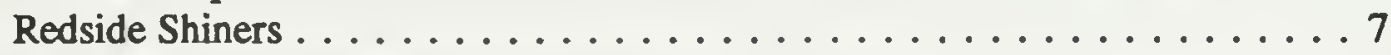

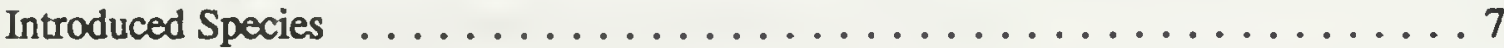

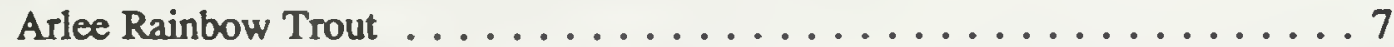

Kamloops Rainbow Trout ..................... 8

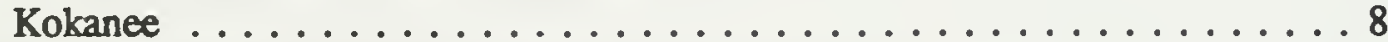

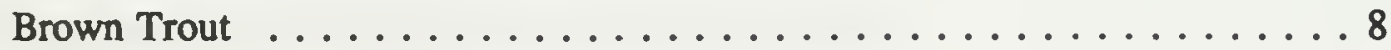

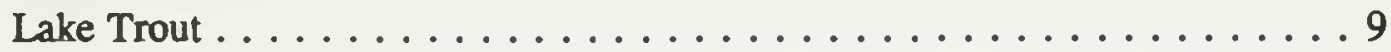

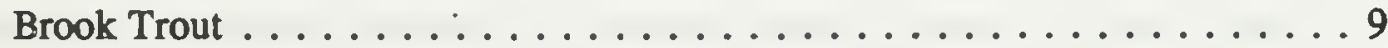

Largemouth Bass . . . . . . . . . . . . . . . . . . . . . 9

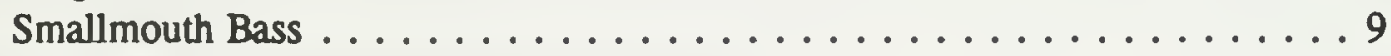

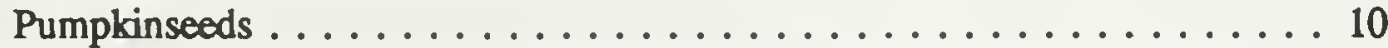

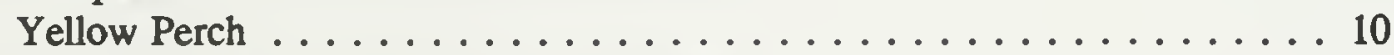

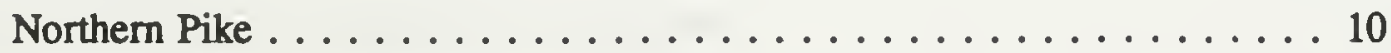

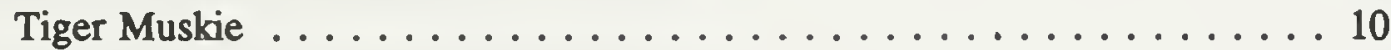

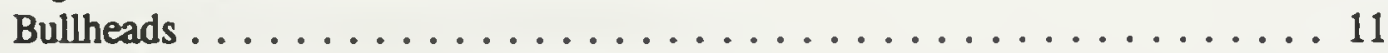

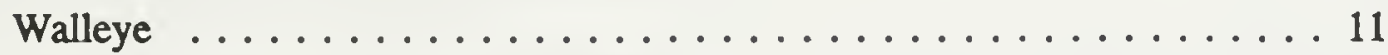

CHEMICAL LAKE REHABILITATION . . . . . . . . . . . . . . . . . . . 13

LAKE DESCRIPTION, MANAGEMENT STATUS, CONCERNS, AND PREFERRED

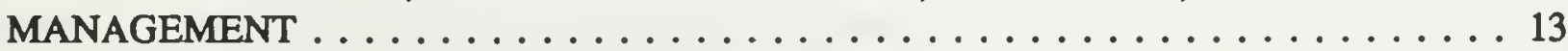

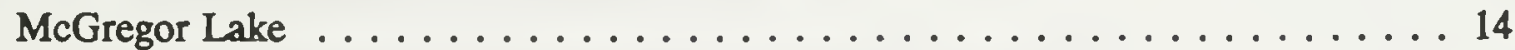

Little McGregor Lake ... . . . . . . . . . . . . . . . . . . . 19

Lower Thompson Lake . . . . . . . . . . . . . . . . . . . . 23

Middle Thompson Lake ........................... 28 
Upper Thompson Lake $\ldots \ldots \ldots \ldots \ldots \ldots \ldots \ldots \ldots \ldots \ldots \ldots \ldots$

Rainbow Lake . . . . . . . . . . . . . . . . . . . . . 37

Crystal and Lavon Lakes $\ldots \ldots \ldots \ldots \ldots \ldots \ldots \ldots \ldots \ldots \ldots$

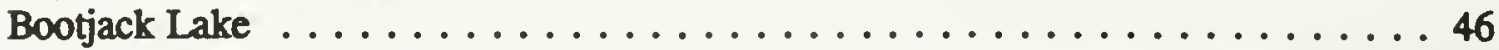

Topless Lake . . . . . . . . . . . . . . . . . . . . . 48

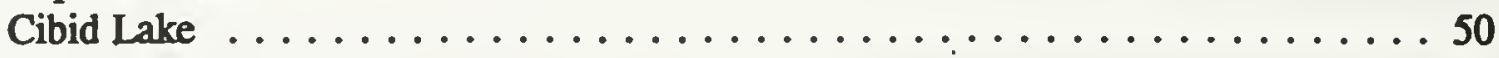

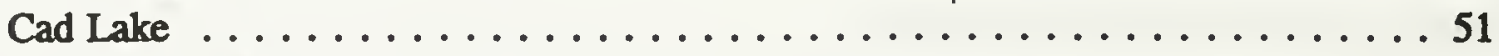

Horseshoe Lake . . . . . . . . . . . . . . . . . . . . 52

Leon Lake . . . . . . . . . . . . . . . . . . . . . 56

Loon and Little Loon Lakes . . . . . . . . . . . . . . . . . 59

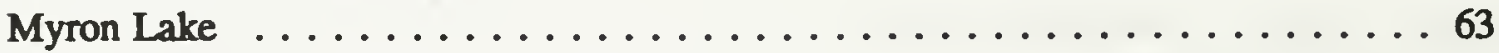

Banana Lake ...........................64

Lost Lake . . . . . . . . . . . . . . . . . . . 65 


\section{LIST OF TABLES}

Page

Table 1. Matrix showing fish species constituency in the Thompson Chain-of-Lakes . . . 12

Table 2. Historic planting of McGregor Lake, 1924-1994 . . . . . . . . . . . . . . . 17

Table 3. Historic planting of Little McGregor Lake, 1938-1994 . . . . . . . . . . . . . 22

Table 4. Historic planting of Lower Thompson Lake, 1930-1994 . . . . . . . . . . . 27

Table 5. Historic planting of Middle Thompson Lake, 1936-1994 . . . . . . . . . . . . 30

Table 6. Summary of spawning run gill-net sets for kokanee in Middle Thompson Lake,

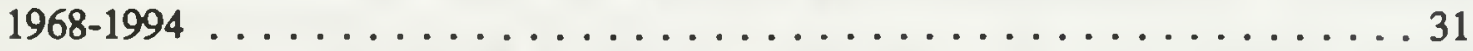

Table 7. Results from bass tournaments held on Middle Thompson Lake, 1989-1993 _ . . 32

Table 8. Historic planting of Upper Thompson Lake, 1936-1994 . . . . . . . . . . . 36

Table 9. Historic planting of Rainbow Lake, $1932-1994 \ldots \ldots$. . . . . . . . . . . . 39

Table 10. Historic planting of Crystal and Lavon Lakes, 1924-1994 . . . . . . . . . . 42

Table 11. Summary of kokanee gillnetting and hatchery stocking rates for Crystal Lake, $1975-1993$. . . . . . . . . . . . . . . . . . . . . . . . 44

Table 12. Historic planting of Bootjack Lake, $1932-1994 \ldots \ldots \ldots \ldots$. . . . . . . 47

Table 13. Historic planting of Topless Lake, 1969-1994 . . . . . . . . . . . . . . . . . 49

Table 14. Historic planting of Cibid Lake, $1973-1994 \ldots \ldots$. . . . . . . . . . . . . . 50

Table 15. Historic planting of Cad Lake, $1972-1994 \ldots \ldots$. . . . . . . . . . . . . 52

Table 16. Historic planting of Horeshoe Lake, 1924-1994 . . . . . . . . . . . . . 55

Table 17. Historic planting of Leon Lake, $1932-1994 \ldots \ldots$. . . . . . . . . . . . . 58

Table 18. Historic planting of Loon and Little Loon lakes, 1931-1977 . . . . . . . . . . 62

Table 19. Historic planting of Myron Lake, $1973-1994 \ldots \ldots \ldots$. . . . . . . . . . 64 


\section{LIST OF FIGURES}

Bage

Figure 1. Map of major lakes included in the Thompson Chain-of-Lakes fisheries management plan .......................... 3

Figure 2. Contour and access map of McGregor Lake, Montana . . . . . . . 15

Figure 3. Contour and access map of Little McGregor Lake, Montana . . . . . . 21

Figure 4. Contour map of Lower Thompson Lake, Montana . . . . . . . . . . 26

Figure 5. Contour and access map of Middle Thompson Lake, Montana . . . . . . . 29

Figure 6. Contour map of Upper Thompson Lake, Montana . . . . . . . . . . . . 35

Figure 7. Contour and access map of Crystal and Lavon lakes, Montana . . . . . 41

Figure 8. Contour and access map of Horseshoe Lake, Montana . . . . . . . . 54

Figure 9. Contour and access map of Leon Lake, Montana . . . . . . . . . . 57

Figure 10. Contour map of Loon Lake, Montana ............... 60

Figure 11. Contour map of Little Loon Lake, Montana . . . . . . . . . . 61 


\section{INTRODUCTION}

The Thompson Chain-of-Lakes (TCL) management area consists of a series of 17 inter-connected and/or adjacent bodies (Figure 1) of water capable of a producing an acceptable fishery in northwest Montana about halfway between Kalispell and Libby. Each year thousands of visitors utilize the lakes in many different ways, including fishing for warmwater, coolwater, and coldwater species of fish. The Montana Fish, Wildlife \& Parks (FWP) has developed this fisheries management plan to aid in attaining state, regional, and site-specific management goals for the TCL.

This plan outlines fisheries management directions for the TCL and was developed in cooperation with a citizen/agency advisory committee. The committee included individuals from a homeowners group, several sportsmens groups, FWP, and the Kootenai National Forest. This plan does not address other concerns such as direction in boating or fishing access, facilities development or land acquisition. Those concerns will be addressed in other plans.

Although the lakes are considered to be parts of a larger unit, the diversity of fisheries and seasonal use of individual lakes necessitates they be considered individually. Lake specific management objectives and strategies can then be brought together to meet system-wide management goals.

This plan states the system-wide fisheries management goals, addresses fisheries information in each lake and reviews the historic and current fish population status of each lake (including past fish management, current sport fishery and current lake regulations, if different from standard regulations). In addition, lake-specific management concerns are presented along with strategies to meet the system-wide and lake management goals. The plan incorporates extensive public input. This plan is designed to guide fisheries management in the Thompson Chain-of-Lakes for ten years at which time the plan would be reviewed and modified as necessary to meet changing management goals. The plan may be modified at any time through adaptive management as new fisheries data or changing public goals dictate.

\section{PUBLIC INVOLVEMENT PROCESS}

The TCL Fisheries Management Plan was initiated in 1995 when background information was assembled into sections on the history and management status of each lake. A TCL Fishery Citizen Advisory Committee was formed and assisted in the identification of management concerns and potential management options for each water. The Committee consisted of the following: 
TCL Fishery Citizen Advisory Committee

\begin{tabular}{|ll|}
\hline Name & Representing \\
\hline Kenneth Drake & Libby Bass Busters \\
Rick Gullingsrud & Libby Bass Busters \\
Herbert Johnson & Flathead Wildlife, Inc. \\
Roland "Red" Kline & TCL Homeowners Association \\
Robert Krepps & Libby Bass Busters \\
Loren Kujawa & TCL Homeowners Association \\
Glen Mueller & Unaffiliated \\
Doug Perkinson & Kootenai National Forest \\
Charlie Decker & FWP Commission \\
\hline
\end{tabular}

A draft fishery management plan was written and mailed directed to more than 250 property owners in the TCL area. In addition, the plan was advertised in the media and copies were distributed from the Kalispell FWP Headquarters, FWP Libby Field Station, and at TCL open houses. A total of 210 comments were received.

The following meetings were held to gather public input on the plan:

\begin{tabular}{|lcl|}
\hline Meeting & Date & Location \\
\hline TCL Homeowners & $1 / 22 / 96$ & Happy's Inn \\
TCL Open House & $3 / 18 / 96$ & Libby \\
TCL Open House & $3 / 28 / 96$ & Kalispell \\
TCL Open House & $5 / 8 / 96$ & Hapoy's Inn \\
\hline \hline
\end{tabular}

Public comments were reviewed by the Citizen Advisory Committee and a preferred management option was formulated that reflected the majority of opinions for each water. In many cases, the preferred option is a blend of two or more of the potential management options. The updated plan was presented to the public one last time in Spring, 1997. The TCL Fishery Management Plan was formally adopted by the FWP Commission on May 30, 1997. 

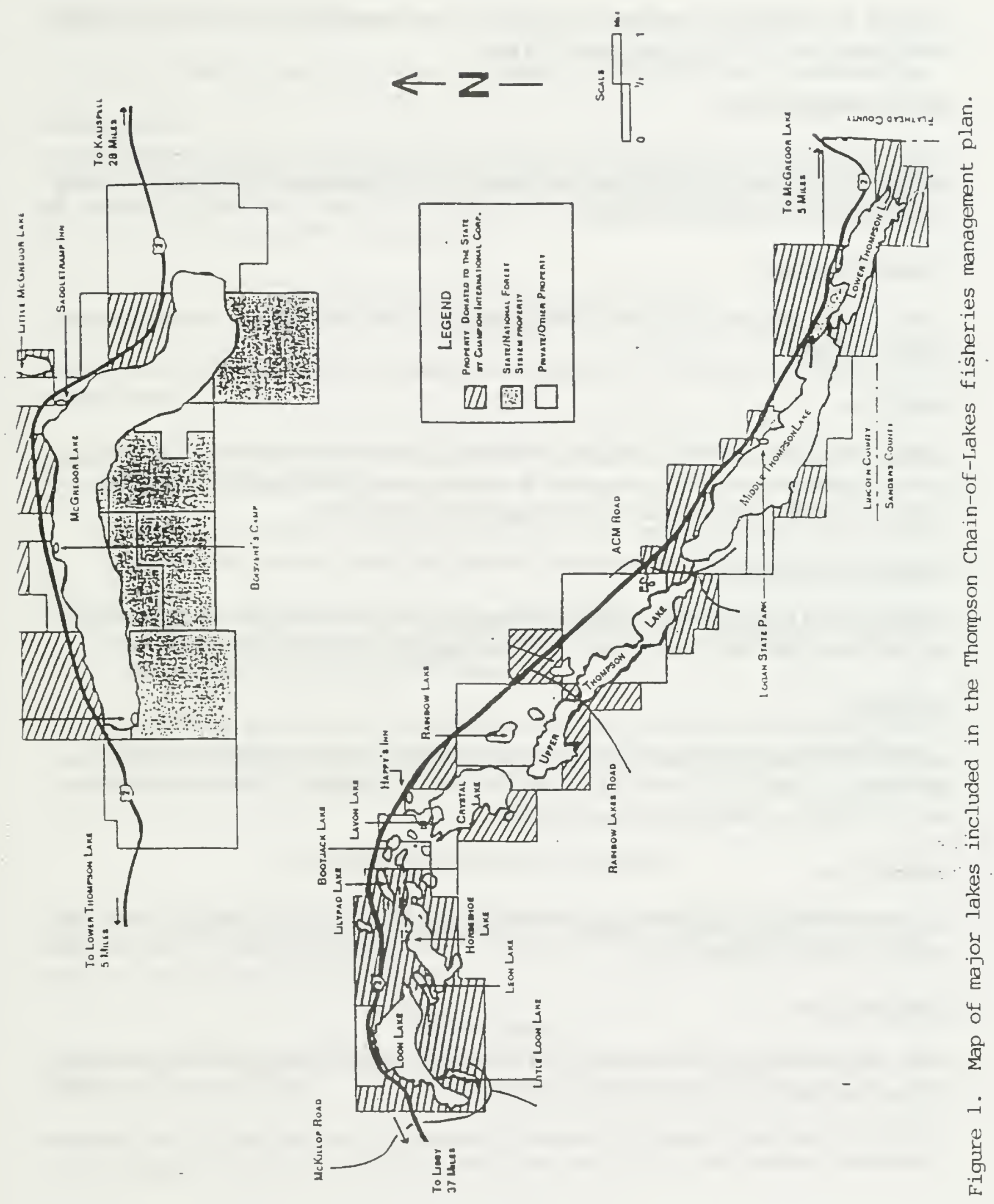
In general the approved plan continues past and present management practices. Following are the major changes that will be pursued under this plan:

\section{Chemical Rehabilitation}

Bootjack, Topless, and Lost lakes will be chemically rehabilitated as funding is available. Little McGregor, Cibid, and Leon lakes will be considered for rehabilitation if changes in stocking cannot overcome rough fish populations.

\section{Habitat Enhancement}

Artificial habitat enhancement for bass will be pursued on the three Thompson lakes and Loon and Little Loon lakes.

\section{Brook Trout}

Stocking ratios in Little McGregor Lake will be shifted to favor brook trout over rainbow trout. An environmental analysis will be conducted to consider adding small numbers of brook trout to some of the small closed-basin lakes now managed for rainbow trout.

\section{Westslope Cutthroat Trout}

Myron Lake will be managed for westslope cutthroat trout. Small numbers of westslope cutthroat trout will be added to some of the small lakes now managed solely for rainbow trout.

\section{Large Trout}

In the 2000-2001 fishing regulation setting process, FWP will propose regulations to produce an opportunity to catch large trout in one of Bootjack, Cad, Cibid lakes, or one of the other small lakes to replace the fishery lost in Notellum Lake.

\section{Northern Pike}

In the 1998-99 fishing regulation process, FWP will propose spearing for northern pike through the ice in Upper Thompson Lake.

\section{Largemouth Bass}

In the 1998-99 fishing regulation process, FWP will propose restrictive regulations for bass during the spawning season in Loon and Little Loon lakes. 


\section{Lost Lake}

After chemical rehabilitation, Lost Lake will be managed for westslope cutthroat and grayling.

\section{Horseshoe Lake}

FWP will prepare an environmental analysis and gather public comment on a proposal to introduce tiger muskie into Horseshoe Lake. FWP will propose a seasonal fishing closure on the western one-third of the lake to protect a bald eagle nest.

\section{SYSTEM-WIDE MANAGEMENT GOALS}

Montana Fish, Wildlife \& Parks will manage the Thompson Chain-of-Lakes consistent with the following goals:

1. Maintain and promote self-sustaining populations of desired cold-cool- and/or warmwater fish species where possible.

2. Provide for a diverse recreational fishery for warm- and/or coldwater fish species consistent with each individual lake's potential and historic use.

3. Provide some opportunity for recreational anglers to capture larger trout ( $>18$ inches) and bass ( $>16$ inches) where consistent with an individual lake's potential; this may include special regulations and/or lake rehabilitation.

4. Recognize the importance of native fishes in the system and manage for a wide diversity of species. Establish a desirable balance between availability, abundance, and distribution of westslope cutthroat trout and rainbow trout.

\section{MANAGEMENT SPECIES ECOLOGY}

The following is a synopsis of the species of fish that exist or are available for management in Thompson Chain-of-Lakes management area. In addition, Table 1 includes a matrix of the species known to exist in individual TCL lakes.

\section{Native Species}

\section{Westslope Cutthroat Trout}

Westslope cutthroat trout are native to northwest Montana. The westslope cutthroat is popular with many anglers because it is a native fish, colorful, and easy to catch. The hatchery broodstock 
for westslope cutthroat in Montana come mostly from fish from the South Fork Flathead River Drainage.

Cutthroat trout spawn in May and June in streams and rivers. The cutthroat is a very catchable fish depending on the time of the year. During the heat of summer, cutthroat will move to cooler, deeper water where they are not as easy to catch. Westslope cutthroat feed mostly on aquatic insects. This trout averages a life span of five years and grows to lengths of 12 to 20 inches.

\section{Mountain Whitefish}

Mountain whitefish are a member of the trout and salmon family and classified as gamefish. They spawn in streams in late fall. They broadcast their eggs over fine gravels in riffles. They feed primarily on insects and zooplankton.

Although whitefish fight well, they are not highly esteemed by most anglers. Their bony nature diminishes their value as table fare although smoked whitefish are highly regarded. Small whitefish provide good prey for large trout and other predators.

\section{Arctic Grayling}

The arctic grayling is native to Montana waters. Male grayling are distinguished by their large sail-like dorsal and beautiful colors. The range of this fish has been greatly reduced due to introductions of non-native species and habitat degradation.

The arctic grayling spawns from late March through early June, depending on water temperatures. Grayling spawn over gravel substrate in smaller streams where they broadcast their eggs. The grayling on average live less than six years but some may live as long as ten years. In Montana the grayling can obtain sizes of 12-18 inches, but are most commonly much smaller. The largest grayling caught in Montana weighed over three pounds. Arctic grayling feed primarily on aquatic insects, and crustaceans, but feed very rarely on fish. Grayling are readily catchable on flies, bait, and small spinners.

\section{Suckers}

Both coarsescale and finescale suckers occur in TCL. Finescale suckers have small, salmon-sized scales and a more pointed nose. Suckers spawn in the spring and broadcast their eggs along lakeshores or over sand and gravel in streams. Spawning males develop a dark red stripe along their sides.

Suckers are intensely disliked by anglers because they compete with gamefish for food, and eat gamefish eggs and angler's bait. Suckers are important to the ecosystem as nature's recyclers but their high fecundity (egg count) makes it easy for them to overwhelm a lake. Suckers are eaten by other fish but most gamefish do not prefer them as prey. 


\section{Peamouth}

Peamouth are a native minnow. They spawn in May and June along lakeshores. They are prolific and can reach nuisance densities. They eat zooplankton and insects.

Peamouth are regarded as a nuisance since they compete with gamefish for food and space and will readily hit angler's bait, flies, and small lures. They are eaten by gamefish but are not a preferred prey.

\section{Northern Squagfish}

Squawfish are the largest minnow in the state. The state record is 7 pounds, 14 ounces from the Clark Fork River. Squawfish spawn in May and June along lakeshores.

Squawfish eat zooplankton and insects and larger squawfish are predatory even though they have no teeth. Anglers detest squawfish because they compete with and eat gamefish and readily hit angler's bait and lures.

\section{Redside Shiners}

Redside shiners are the smallest minnow in TCL, growing to only $4^{n}-5^{n}$. They are prolific and can quickly reach nuisance numbers. Although they are a preferred prey of many gamefish, they can outcompete gamefish for food and will eat gamefish eggs.

\section{Introduced Species}

\section{Arlee Rainbow Trout}

The Arlee strain of rainbow trout originated in 1955 at the State Fish Hatchery in Arlee, Montana. It is the result of a cross between the Donaldson rainbow strain and McCloud River (Califomia) rainbow/steelhead cross created in Missouri. This strain of rainbow has been limited to the hatcheries for its broodstock. The Arlee strain is widely planted by FWP.

The Arlee rainbow spawns in mid August through early January in the hatcheries, but most likely does not spawn successfully in the wild. It has good disease resistance and fast growth; they commonly grow up to 18 inches and 2 pounds with some more than 10 pounds. A 16-pound Arlee rainbow was taken from Crystal Lake several years ago. Arlee rainbow trout are characterized as generalists, feeding primarily on zooplankton and insects. They have a short life expectancy; most live two years in the wild but some may live four years or longer. In northwest Montana most Arlee rainbows grow $2^{n}-3^{n}$ per year and because of their life expectancy are harvested at $12^{\prime \prime}-16^{n}$ in length. They are easily catchable by anglers which contributes to their short life expectancy. 


\section{Kamloops Rainbor Trout}

Kamloops trout are a strain of rainbow trout that originated in the north arm of Kootenay Lake in British Columbia. The broodstock for this strain are from trout that spawned in the Duncan River from Kootenay Lake. The kamloops has been planted by FWP in several western Montana lakes.

The kamloops spawn from mid March through June, on average, but discharge and temperature may shift the timing of the spawning. The kamloops is long-lived and is known for becoming very large (over 20 pounds). It obtains the large sizes by feeding heavily on fish (primarily kokanee) once it reaches a size of 12 inches. Because of the kamloops ability to reach large sizes they highly sought after game fish, but its catch rate is very low (.02 fish per hour on average in some lakes). Kamloops are not readily available at this time.

\section{Kokanee}

Kokanee salmon are the landlocked form of Pacific sockeye salmon. Kokanee are widely planted in Montana and the Pacific Northwest. The broodstock for northwest Montana originated through Flathead Lake from Canada. Currently eggs are taken from wild kokanee in several northwest Montana lakes.

Kokanee generally spawn in the tributaries of their home lake but often times will use spring areas in the lake. Kokanee dig shallow spawning nests or redds in small gravel. Salmon die after they spawn. This salmon appears to have limited reproduction in Middle Thompson Lake and Crystal Lake, but most likely will not reproduce successfully in other TCL lakes because they are closed basins and have limited spring influence. Kokanee generally feed primarily on zooplankton and on aquatic insects when they are abundant. The life expectancy of kokanee is fairly short, most spawn and die in three years, some will live to five years. The average kokanee in northwest Montana is $10^{\prime \prime}-12^{\prime \prime}$ although some kokanee in the Thompsons will exceed 20 inches. Kokanee are catchable by a number of methods and are prized by anglers for fighting and eating qualities.

\section{Brown Trout}

Brown trout are widely established in the lower Clark Fork Drainage. They have been planted in the Thompson Lakes and upper Thompson River but do not appear to have established selfsustaining populations. Brown trout spawn in the fall in streams.

Brown trout eat insects when small but become very predacious when large. They can grow to 10-20 pounds. Most anglers find them difficult to catch. 


\section{Lake Trout}

Lake trout, also known as mackinaw, are actually a char. They prefer to live in cold, deep lakes and spawn in 10-20 feet in water in late fall. They broadcast their eggs over gravel and rubble. Lake trout eat insects when young but become highly predacious after they reach $12^{\prime \prime}-14^{\prime \prime}$.

Lake trout readily hit angler's lures but their deep-dwelling habits require some special techniques. Lake trout commonly reach 2-5 pounds but can grow to more than 20 pounds. Small lake trout are delicious but larger lake trout become very oily. Lake trout can over-reproduce and become stunted.

\section{Brook Trout}

Brook trout are a char, a relative of lake trout. They spawn in the fall in lakeshore spring areas or in small streams. They can over-reproduce and become stunted. Brookies usually range from $8^{n}-12^{n}$ in length.

Brook trout eat insects, zooplankton and small fish. They are readily catchable and quite tasty. They tend to outcompete many other gamefish.

\section{Largemouth Bass}

Largemouth bass is not native to Montana but was introduced into the Flathead River system in 1898 by the U.S. Bureau of Fisheries.

Spawning occurs in late spring to early summer, once water temperatures reach about $60^{\circ}$ Fahrenheit $(F)$. Largemouth bass spawn by fanning a shallow depression in sand or mud near aquatic vegetation. Female bass produce about 5,000-7,000 eggs per pound of body weight. Male bass tend the nests, fanning the eggs and protecting the young and fry from predators. Bass frequent shallow water with heavy cover such as weeds and logs. The largemouth's diet includes zooplankton, insects, and fish. They are somewhat easier to catch than smallmouth bass but probably because they are in higher densities in TCL lakes. Northwest Montana is at the northern-most range for bass so they are slow growing. They commonly reach $12^{n}-16^{n}$ in 5-8 years, although some grow to 3-5 pounds and 15 years of age.

\section{Smallmouth Bass}

Smallmouth bass are not native to Montana, but were introduced into the Clark Fork, Flathead and Kootenai River drainages in western Montana. They were first introduced into Montana in 1910.

The smallmouth bass spawn in rock or graveled substrates along lakeshores from mid-April through July. Smallmouths prefer cool waters and rocks and rubble for cover. Smallmouths are more temperature dependent than largemouths and they become inactive at high water temperatures and below $50^{\circ} \mathrm{F}$. The smallmouth grows commonly to lengths of 7-16 inches and 
2-3 pounds. They feed on zooplankton and insects as young, and as adults they feed primarily on fish and crayfish. The smallmouth is generally a long-lived, slow growing species. They are highly esteemed by anglers for their fighting ability.

\section{Pumpkinseeds}

Pumpkinseeds are commonly referred to as sunfish. They spawn in spring along lakeshores by fanning out small saucer-shaped depressions. They eat zooplankton, insects, and fish fry. They generally do not grow larger than six inches.

Pumpkinseeds are tasty if large enough to fillet and are readily catchable by kids. Pumpkinseeds readily hit bait and small lures but can reach nuisance densities and impact other gamefish. Their saucer shape and spiny fins make them a poor prey species.

\section{Yellow Perch}

Yellow perch spawn in spring along lakeshores in 2-10 feet of water. They broadcast strings of eggs over vegetation. Perch eat zooplankton, insects, and small fish.

Perch are very tasty and highly sought after if they reach $8^{n}-12^{n}$. Unfortunately perch tend to stunt out. Perch are readily catchable and very popular with young anglers. Perch tend to inhabit all areas of lakes and are fierce competitors with other fish. Their spiny fins make them undesirable prey.

\section{Northern Pike}

Northern pike were illegally introduced into this area in the 1950s and are now widespread. Pike spawn in the spring by broadcasting adhesive eggs over vegetation in shallow water. Pike quickly become predators and chiefly eat fish. They prefer to live in heavy cover in shallow water where they can ambush their prey.

Pike are fast-growing and commonly reach 5-10 pounds and can grow over 20 pounds. They are highly prized by some anglers for the fighting and eating qualities, but hated by others because of their predacious nature. Pike do eat some trout and salmon, but food habit studies have shown that they eat primarily suckers, peamouth, and squawfish which inhabit heavy cover with pike.

\section{Tiger Muskie}

The tiger muskie is the result of the cross breeding of a female muskellunge and a male northern pike. Tiger muskies are very adaptable to temperature and turbidity. The tiger muskie has been planted in northeast Montana and grown to over 40 inches in length.

The tiger muskie is sterile and does not spawn. It is known for its good eating, fast growth, moderate catch rates, and large trophy size. It is highly piscivorous and prefers soft-ray finned fish, minnows, suckers, etc., over spiny-ray finned fish like yellow perch and pumpkinseeds. 


\section{Bullheads}

Bullheads are a member of the catfish family. They spawn in spring. They are easily catchable and tasty if large enough $\left(8^{n}-12^{n}\right)$ and if caught from cool, clean water. However, they easily stunt out and readily outcompete many other gamefish. They make poor prey because of stiff spines in their dorsal and pectoral fins.

\section{Walleye}

Walleye are included here because they are commonly requested for gamefish introductions. FWP contracted an independent assessment of walleye in 1989. That report showed that when walleye are mixed with trout and salmon, the trout and salmon will be heavily impacted or eradicated. Because of the interconnected nature of many waters such as TCL and the high incidence of illegal transplants, it was obvious that if walleyes were planted West of the Divide they would end up harming many existing fisheries. Therefore, the FWP Commission banned the introduction of walleye West of the Divide so they are not available for management in TCL. Despite the seriousness of the problem, there have been five documented, but so far unsuccessful, illegal transplants of walleyes West of the Divide since 1989. 


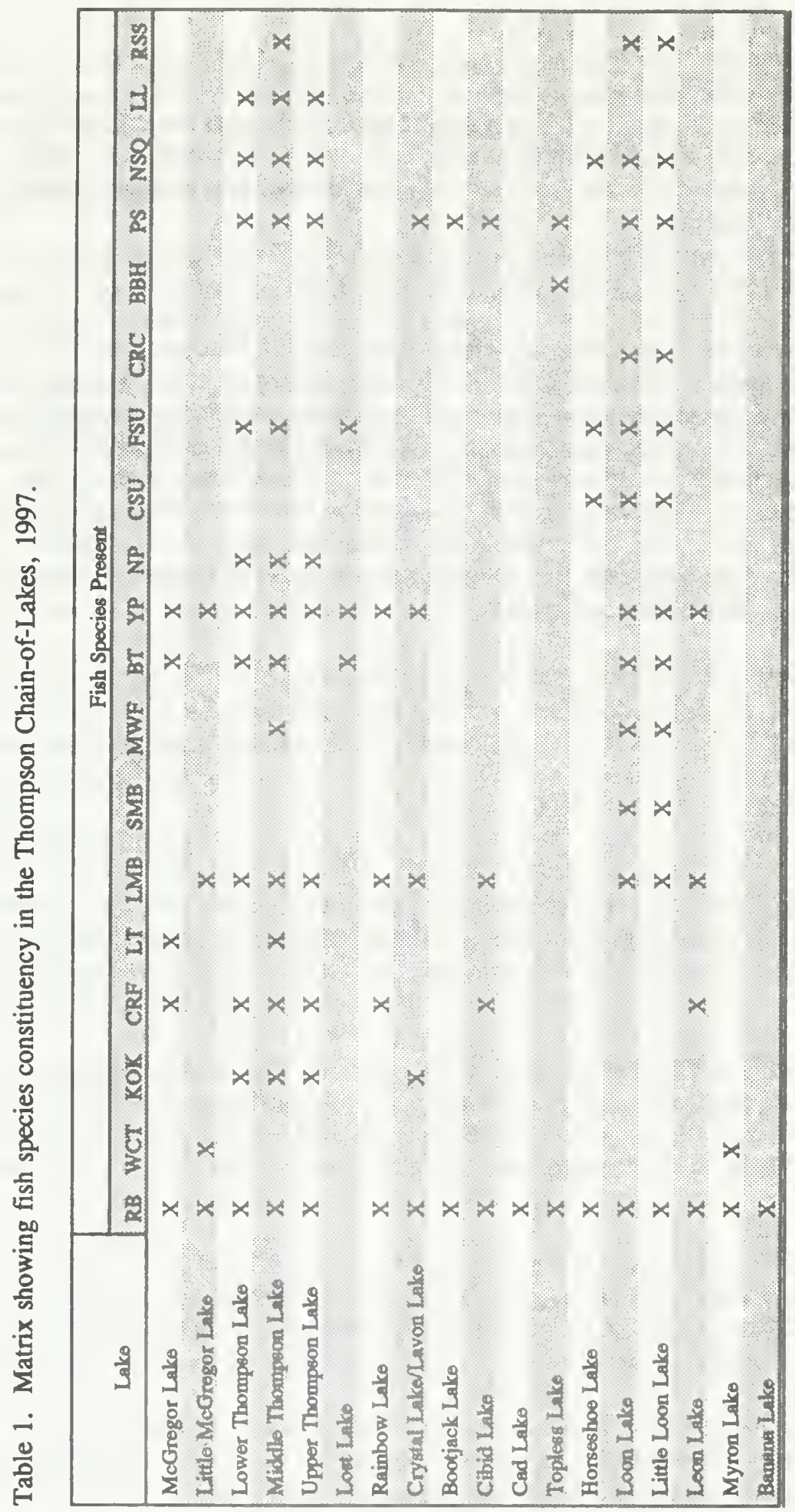

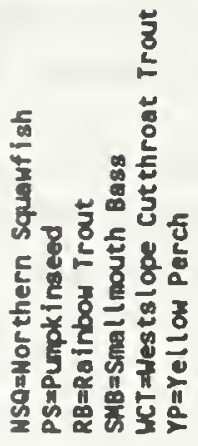

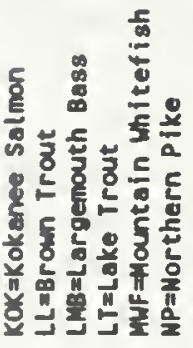




\section{CHEMICAL LAKE REHABILTATION}

In some instances, a fishery may become overwhelmed by unwanted fish species such as shiners or suckers that compete with gamefish for food and space or prey directly on eggs or small fry. Even desirable fish such as perch and brook trout can over-reproduce in some instances and stunt out at a small size. In some cases fish biologists may choose to remove all the fish from a lake or pond and start over. This is known as a chemical rehabilitation or "rehab". Biologists use a fish toxicant called rotenone which comes from a South American plant. Rotenone kills fish by interfering with the transfer of oxygen from gills into the bloodstream. Rotenone is approved by the Food and Drug Administration when applied by a licensed applicator. FWP will go through a public involvement process and obtain a permit from the Department of Environmental Quality prior to any rehab.

Fish killed with rotenone are technically fit for consumption but because the condition of the fish is unknown and rotenone has a petroleum mixing agent that may give an off flavor, FWP discourages salvage. Dead fish are collected when necessary for off-site disposal.

Rotenone is fairly specific to fish but may kill some gill-breathing organisms such as crayfish and dragonfly nymphs. Those will usually quickly repopulate. Rotenone will not affect mammals or birds. Rotenone can be detoxified if needed, but usually breaks down quickly into common organic components when exposed to heat, air, and sunlight.

\section{LAKE DESCRIPTION, MANAGEMENT STATUS, CONCERNS AND PREFERRED MANAGEMENT}

Following are water by water descriptions of the past fish management and stocking histories of each TCL lake along with present management concerns. The alternative management strategies are noted and the preferred management strategy as chosen by the TCL Fishery Citizen Advisory Committee through public input is detailed. 


\section{MCGREGOR LAKE}

\section{Lake Description:}

McGregor Lake is a large, deep lake 35 miles west of Kalispell, Montana. The lake has small inlets and one small outlet (McGregor Creek) that connects it to the Clark Fork River through the Thompson River. Its maximum depth is 220 feet and approximately 80 percent of the depth of the lake is greater than 100 feet. McGregor Lake has a surface area of 1,328 acres (Figure 2). A small impoundment structure regulates outflow from McGregor Lake. The impoundment controls the upper three feet of lake elevation. The structure is a barrier to upstream migration. Between March 1, 1993 and February 28, 1994, FWP estimated that as many as 6,975 anglers, of which 82 percent were Montana residents, fished at McGregor Lake. This information is gathered by FWP through creel surveys and phone interviews on licensed anglers and is produced in the Montana Statewide Angling Pressure Report.

\section{Lake Management Status:}

Management of McGregor Lake commenced in 1924 when 90,000 coho salmon were planted (Table 2). Various species of fish including rainbow trout, cutthroat trout, and arctic grayling were also stocked with poor results due to poor spawning success. Brook trout did manage to establish a small, self-reproducing population from a single plant of 4,000 fish in 1947. These hatchery plants were added to already existing populations of native westslope cutthroat trout, mountain whitefish, longnose suckers, northern squawfish, and redside shiners. Yellow perch were also established through illegal introductions sometime in the past.

In 1942, the initial stocking of lake trout occurred. Subsequent stocking of lake trout from 1948 through 1953 established a self-reproducing population. Beginning in 1965, FWP began stocking kokanee salmon in McGregor Lake to produce a fishery similar to Flathead Lake and Whitefish Lake. FWP also continued to stock rainbow trout to produce a "three-tiered" effect that included a consumptive kokanee/rainbow fishery and trophy lake trout fishery. McGregor Lake produced relatively good numbers and sizes of rainbow trout (14 inches to occasionally 10 pounds), kokanee (11 to 20 inches), and lake trout (average 18 inches to occasionally 25 pounds).

In 1968, FWP introduced the opossum shrimp (Mysis relicta). The desired effect was to create a large kokanee (up to 5 pounds) similar to those being captured in Kootenay Lake, British Columbia. The result was not as expected. In deep lakes, Mysis tend to live near the lake bottom during the daylight hours and rise to near the surface to feed at night. Two major outcomes resulted from the Mysis introduction. 


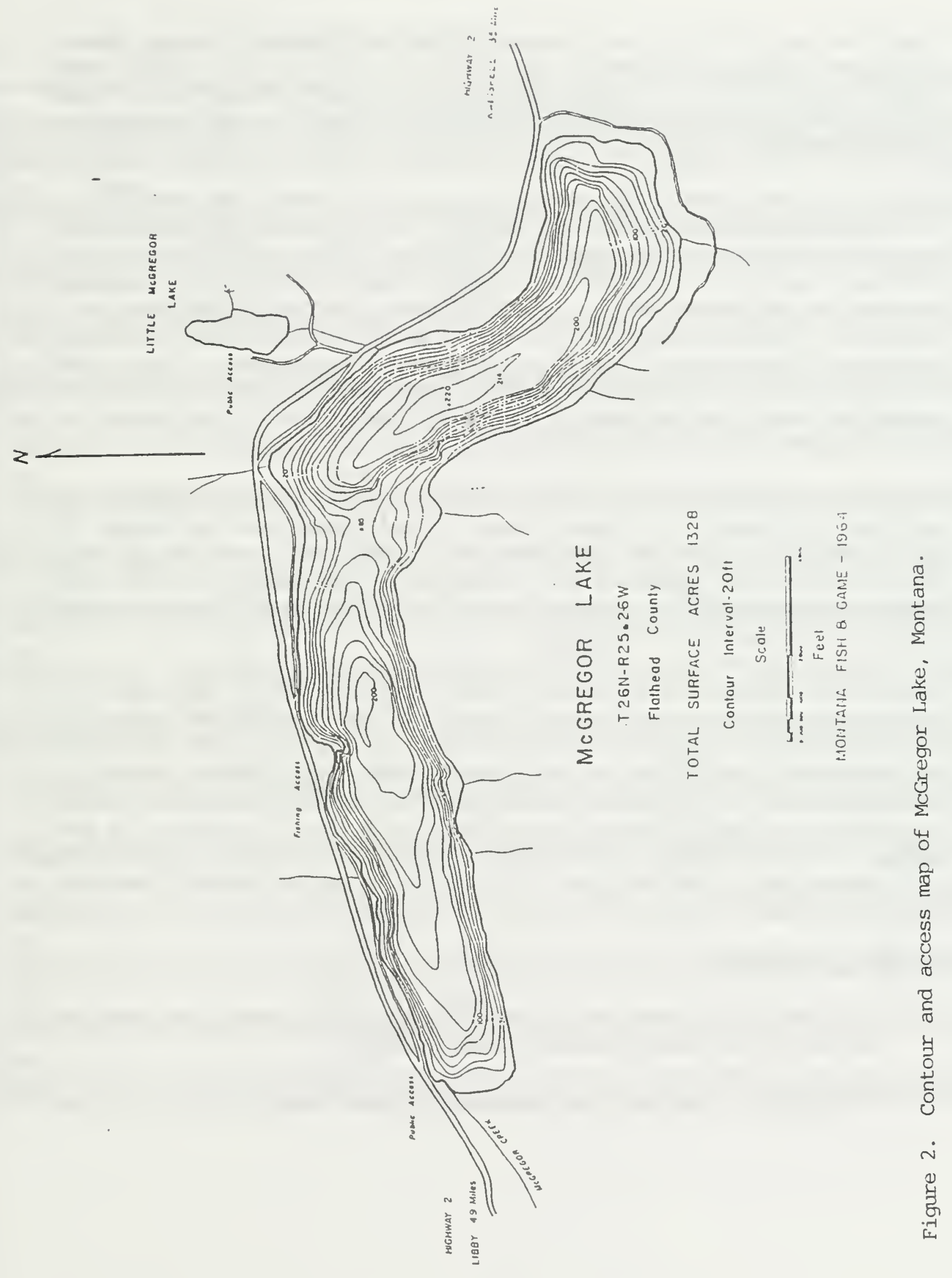


First, Mysis feed on the same small organisms (zooplankton) that kokanee prefer. Because kokanee feed mainly near "thermocline" (generally 15 to 45 feet below the surface) during daylight hours, the kokanee rarely got opportunities to feed on Mysis. Not only were the Mysis not being eaten by the kokanee, they were competing successfully for the same zooplankton on which kokanee fed.

The second outcome of Mysis introduction to McGregor Lake was related to lake trout. Prior to Mysis introductions, lake trout existed at lower densities. Lake trout tend to live near the bottom of the lake especially as fry and fingerlings. Young lake trout that were too small to begin feeding on fish had to survive on the relatively small numbers of aquatic invertebrates and zooplankton that existed near the bottom of the lake. In effect, there was a "bottleneck" that allowed only a small number of young lake trout to survive to grow large enough to feed on fish (i.e. kokanee, rainbow trout, redside shiners). When Mysis were introduced, the bottleneck no longer existed for young lake trout. Many more young lake trout could survive on this new food source that existed at the bottom of the lake during the daytime, they survived in much larger numbers to a size that could eat kokanee, which they did.

The combined result of the Mysis introduction was that food supplies dwindled for kokanee; this made them more susceptible to predation because they had to spend more time foraging. In addition, the lake trout were in such high densities that a "predator trap" was created that greatly reduced kokanee survival. Future stocking of kokanee was no longer feasible and in 1985, FWP discontinued stocking kokanee in McGregor Lake. In addition, the lake trout became stunted as numbers increased and kokanee disappeared.

Currently, FWP manages McGregor Lake as a lake trout/rainbow trout fishery. Most anglers now fish for lake trout which are popular due to high catch rates (both in summer and winter). The flesh of lake trout in McGregor Lake is "pink" due to Mysis in their diet. Lake trout less than eight pounds tend to have this pink flesh and are excellent tasting. Fifty thousand rainbow trout are stocked annually because there is no significant natural reproduction in the lake. Rainbow trout provide a reasonable spring and winter fishery mostly along the shoreline, but their abundance is limited by lake trout predation. Catches range from $8^{\prime \prime}$ to $18^{\prime \prime}$ and 3 to 5 pound trout are sometimes caught. In addition, yellow perch provide a limited, self-sustaining fishery with very few large fish.

\section{Management Concerns:}

1. FWP is not sure if rainbow trout can exist in McGregor Lake at levels greater than what currently exist due to high predator (lake trout) densities.

2. The population of lake trout is comprised mostly of smaller fish. 
Table 2. Historic planting of McGregor Lake, 1924-1994.

\begin{tabular}{|c|c|c|c|c|c|c|c|c|}
\hline \multicolumn{9}{|c|}{ Number of Fish Planted } \\
\hline Year. & $\begin{array}{l}\text { Coho } \\
\text { Sthoman }\end{array}$ & $\begin{array}{l}\text { Rainbaw } \\
\text { Trout }\end{array}$ & $\begin{array}{l}\text { Cutthrout } \\
\text { Trout }\end{array}$ & $\begin{array}{l}\text { Anctio } \\
\text { Groyling }\end{array}$ & Kokanee & Leke Trout & $\begin{array}{l}\text { Brook } \\
\text { Trout }\end{array}$ & $\begin{array}{l}\text { Woetslopo } \\
\text { Cutthroet Trout }\end{array}$ \\
\hline 1924 & 90,000 & & & & & & & \\
\hline 1925 & 100,000 & & & & . & & & \\
\hline 1926 & & 260,000 & 240,000 & 796,000 & & & & \\
\hline 1927 & & 60,000 & $\therefore \quad \therefore$ & 700,000 & $\therefore$ & & & \\
\hline 1929 & & 264,000 & & 206,200 & & & & \\
\hline 1931 & & 30,000 & & & & & & \\
\hline 1933 & & & & 100,000 & & & & \\
\hline 1934 & & 46,400 & & 4 & & 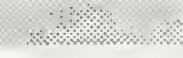 & & \\
\hline 1935 & & & 90,000 & & & & & \\
\hline 1936 & & 35,000 & . & 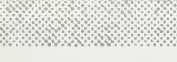 & w & W & ( & s. \\
\hline 1937 & & & 75,000 & & & & & \\
\hline 1939 & & & 7,000 & & & & & \\
\hline 1940 & & & 49,000 & & & & & \\
\hline 1941 & & & 20,000 & & m. & 4.4 & & \\
\hline 1942 & & 4,500 & 200 & & & 9,600 & & \\
\hline 1943 & & 11,050 & & & $\cdots$ & & & \\
\hline 1944 & & 7,337 & & & 22,500 & & & \\
\hline 1945 & & 6,368 & & & . & 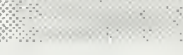 & 1. & \\
\hline 1946 & & 13,320 & & & & & & \\
\hline 1947 & & $\%$ & & & & $\therefore \%$ & 4,000 & \\
\hline 1948 & & 4,000 & & & & 10,976 & & \\
\hline 1949 & & 52,000 & & & & 15,400 & 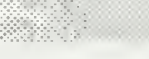 & \\
\hline 1950 & & & & & & 11,600 & & \\
\hline 1951 & & m & 48,000 & & 55,000 & 21,000 & & \\
\hline 1952 & & 12,000 & 56,284 & & & 25,360 & & \\
\hline 1953 & & & 27,500 & & & 31,200 & & \\
\hline 1954 & & & 300,330 & & & & & \\
\hline 1955 & & & 165,120 & & & & & . \\
\hline 1956 & & & 163,000 & 100,000 & & $\sqrt{x}$ & & \\
\hline 1957 & & & 164,000 & 210,000 & & & & \\
\hline 1958 & & & 157,000 & & & & & \\
\hline 1959 & & & 304,798 & & & & & \\
\hline
\end{tabular}


Table 2. Continued.

\begin{tabular}{|c|c|c|c|c|c|c|c|c|}
\hline \multicolumn{9}{|c|}{ Number of Fish Planted } \\
\hline Yoar & $\begin{array}{c}\text { Coho } \\
\text { Salmona }\end{array}$ & $\begin{array}{c}\text { Raiphow } \\
\text { Trout }\end{array}$ & $\begin{array}{c}\text { Cuthroat } \\
\text { Trout }\end{array}$ & $\begin{array}{l}\text { Arctic } \\
\text { Graylins. }\end{array}$ & Kokanos & Lake Trout & $\begin{array}{l}\text { Brook } \\
\text { Trout }\end{array}$ & $\begin{array}{l}\text { Wostalope } \\
\text { Cuthrone Trout }\end{array}$ \\
\hline 1960 & & & 125,456 & & & & & \\
\hline 1965 & & & & & 212,000 & & & \\
\hline 1966 & & 42,000 & & & 293,000 & & & \\
\hline 1967 & & 22,040 & & & 273,408 & & & \\
\hline 1968 & & 22,400 & & & 600,262 & & & \\
\hline 1969 & & 20,005 & 33,070 & & $\% \div$ & & & \\
\hline 1970 & & & & & 157,500 & & & \\
\hline 1971 & & 20,650 & $\therefore . .$. & & 220,720 & & & \\
\hline 1972 & & 40,250 & 67,340 & & 300,000 & & & \\
\hline 1973 & & 20,000 & & & 300,000 & & & \\
\hline 1974 & & & & & 300,000 & & & \\
\hline 1975 & & & & & 300,000 & & & 39,960 \\
\hline 1976 & & & & & 150,000 & & & 33,048 \\
\hline 1977 & & & & & 100,000 & & & 43,004 \\
\hline 1978 & & & & & 300,000 & & & 38,250 \\
\hline 1979 & & & & & 100,000 & & & 40,045 \\
\hline 1980 & & & & & 100,000 & & & 39,994 \\
\hline 1981 & & & & & & & & 37,525 \\
\hline 1982 & & 40,146 & & & 85,000 & & & \\
\hline $1983^{\circ}$ & & 95,541 & & & 100,000 & & & \\
\hline 1984 & & 95,634 & & & 100,000 & & & \\
\hline 1985 & & 76,071 & & & 75,000 & & & \\
\hline 1986 & & 71,823 & & & & & & \\
\hline 1987 & & 75,839 & & & 1 & & & \\
\hline 1988 & & 71,382 & & & & & & \\
\hline 1989 & & 47,700 & & & (2. & & & \\
\hline 1990 & & 51,797 & & & & & & \\
\hline 1991 & & 60,652 & & & & & & \\
\hline 1992 & & 53,786 & & & & & & \\
\hline 1993 & & 65,708 & & & & & & \\
\hline 1994 & & 50,000 & & & & & & \\
\hline
\end{tabular}




\section{Prefecred Manяgement Option:}

Management options considered included current management for both rainbow and lake trout, management for lake trout only, management for trophy lake trout, increased rainbow trout plants, kokanee plants, yellow perch enhancement, or introducing lake trout prey. There were 84 comments on McGregor Lake.

Under the preferred management option, McGregor Lake would be managed as a lake troutrainbow trout fishery. Through monitoring and adaptive management, lake trout regulations might be altered to promote larger fish. This might include slot limits and/or liberalization of take of smaller lake trout. Rainbow trout would be stocked with emphasis on multiple planting sites to decrease predation by lake trout. Interested anglers would be recruited to assist by making midlake boat plants. Rainbow trout stocking would be monitored and might be modified if current stocking prove to be fruitless.

\section{LTTTLE MCGREGOR LAKE}

\section{Lake Description:}

Little McGregor Lake is a medium-sized lake north of McGregor Lake that connects to McGregor Lake through an intermittent unnamed creek. The maximum depth of Little McGregor Lake is 33 feet, mean depth is 13 feet and it has a surface area of 33 acres (Figure 3). Between March 1, 1993 and February 28, 1994, FWP estimated that as many as 1,212 anglers, of which 100 percent were Montana residents, fished at Little McGregor Lake (Montana Statewide Angling Pressure Report).

\section{Lake Management Status:}

Management of Little McGregor Lake commenced in 1938 when 7,000 cutthroat trout were planted. In 1961, the lake was poisoned to remove a well-established population of illegally stocked black bullheads. With the exception of an unsuccessful bull trout plant in 1945, Little McGregor Lake was maintained as a brook trout fishery until 1985 (Table 3). In the mid-1980's, the angling public expressed a desire for more angling opportunities in the region. Because brook trout fishing can be slow during summer months, FWP planted cutthroat trout in Little McGregor Lake to create a "two-tiered" fishery. The experiment met with good success and the two-tiered management continued. Since 1988, the cutthroat trout have been replaced with rainbow trout to better compete with the other species illegally transplanted into the lake.

Little McGregor Lake was surveyed with gill nets in 1992. We found that sometime between 1983 and 1992, yellow perch and largemouth bass were illegally introduced into Little McGregor Lake. Yellow perch are now well established while largemouth bass are in low numbers in the lake. Relative numbers of rainbow/cutthroat trout are still good ( 9.1 per net) and their condition 
is better than all of the other lakes in TCL. Relative numbers of brook trout are down from a 1983 inventory (6.0 per net and 1.0 per net for 1983 and 1992, respectively). This is probably due to increased predation (on fry) and competition (with adults) with the introduced yellow perch.

Although not covered in this fishery management plan, the need for legal access and the poor condition of the road are frequently mentioned concerns.

\section{Management Concerns:}

Yellow perch introduced to lakes in northwest Montana have shown tendencies to produce stunted populations after an initial boom of large perch. When this happens, naturally reproduced fry (like brook trout) and planted fry (rainbow trout and cutthroat trout) are highly susceptible to predation. In addition, the high densities of yellow perch that compete for food and space may reduce both growth and survival of the game fish. Stocking becomes less successful and hatcheries must produce a larger (and more expensive) trout to maintain survival.

\section{Breferred Management Option:}

Management options considered included current management and trout stocking, chemical rehab and restock with trout, adjust trout stocking rates, manage for yellow perch, and add a predator such as pike to control perch. There were 57 comments on Little McGregor Lake.

Under the preferred management option, Little McGregor Lake would be managed as a brook trout/rainbow trout/yellow perch fishery. Through monitoring and adaptive management, stocking rates and sizes of rainbow trout and brook trout will be altered to produce a satisfactory fishery and to shift emphasis back to brook trout. The lake would be rehabbed and returned to a trout fishery if the yellow perch overwhelm the fishery. 


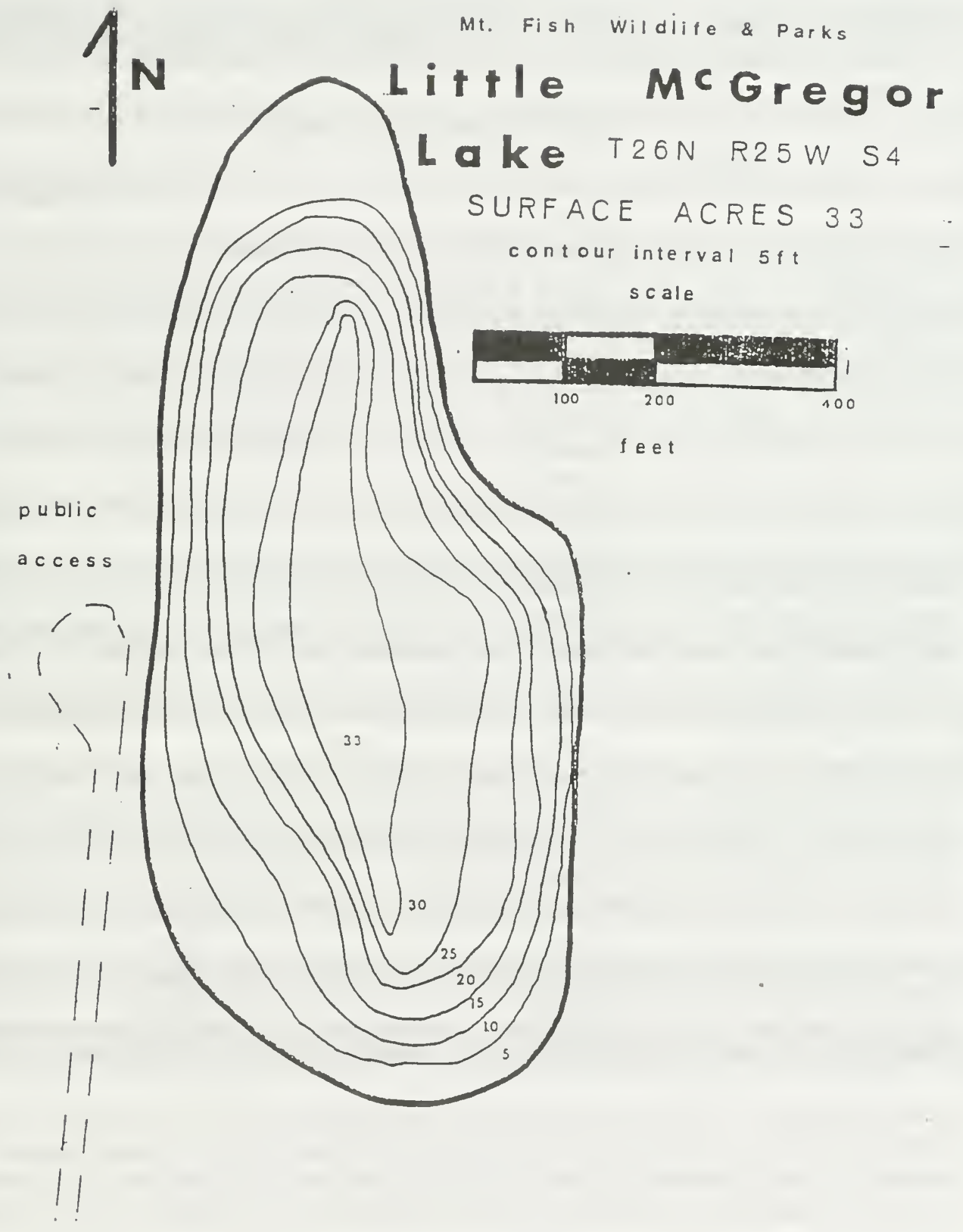

Figure 3. Contour and access map of Little McGregor Lake, Montana. 
Table 3. Historic planting of Little McGregor Lake, 1938-1994.

\begin{tabular}{|c|c|c|c|c|c|c|}
\hline \multirow[b]{2}{*}{ Year } & \multicolumn{6}{|c|}{ Number of Fish Planted } \\
\hline & $\begin{array}{l}\text { Cutthrout } \\
\text { Trout }\end{array}$ & $\begin{array}{l}\text { Bub } \\
\text { Troot }\end{array}$ & $\begin{array}{l}\text { Brook } \\
\text { Trout }\end{array}$ & $\begin{array}{l}\text { Westslopo Cuthroat } \\
\text { Trout }\end{array}$ & $\begin{array}{l}\text { Arles } \\
\text { Rainbow Trout }\end{array}$ & $\begin{array}{l}\text { Kemloops Reainbot } \\
\text { Trout }\end{array}$ \\
\hline 1938 & 7,000 & & & & & \\
\hline 1943 & & & 20,000 & & & \\
\hline 1945 & & 53,000 & & & & \\
\hline 1962 & & & 22,188 & & & \\
\hline 1963 & & & 6,480 & & & \\
\hline 1964 & & & 6,510 & & & \\
\hline 1965 & & & 6,400 & & & \\
\hline 1966 & & & 4,800 & 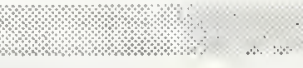 & & \\
\hline 1967 & & & 3,000 & & & \\
\hline 1968 & & & 3,600 & & & \\
\hline 1970 & & & 3,007 & & & \\
\hline 1971 & & & 3,000 & & & \\
\hline 1972 & & & 6,000 & & & \\
\hline 1974 & $\cdot i$ & & 3,025 & $\%$ & & \\
\hline 1976 & & & 3,113 & & & \\
\hline 1977 & & & 3,003 & & & \\
\hline 1978 & & & 3,068 & & & \\
\hline 1981 & 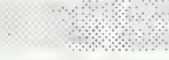 & & 3,000 & & & \\
\hline 1982 & & & 4,000 & & & \\
\hline 1983 & & & 4,000 & & & \\
\hline 1985 & & & 6,075 & 3,000 & & \\
\hline 1986 & & & 8,000 & & & \\
\hline 1987 & & & 16,000 & & 5,005 & \\
\hline 1988 & & & 8,155 & 2,083 & . & \\
\hline 1989 & & & 8,000 . & & & \\
\hline 1990 & & & $\%$ & 1,992 & 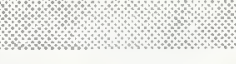 & 3,264 \\
\hline 1991 & & & 1,999 & & 2,016 & \\
\hline 1992 & & & 2:- & & 2,044 & \\
\hline 1993 & & & 6,024 & & 2,184 & \\
\hline 1994 & & & 6,000 & & 2,000 & \\
\hline
\end{tabular}




\section{THOMPSON LAKES}

The Thompson lakes are a series of three lakes connected by shallow water ways. Although the channels that connect the lakes are passable to fish, the lakes will be considered as separate management units for the purposes of this document.

\section{LOWER THOMPSON LAKE}

\section{Lake Description:}

Lower Thompson Lake is a medium-sized lake that is the most downstream of the chain of TCL. It is the source of the Thompson River which flows into the Clark Fork River. The channel that connects Lower Thompson Lake to Middle Thompson Lake is fairly wide and of sufficient depth to pass fish. The lake has a maximum depth of 140 feet and a surface area of 240 acres (Figure 4). Between March 1, 1993 and February 28, 1994, FWP estimated that as many as 2,538 anglers, of which 98 percent were Montana residents, fished at Lower Thompson Lake (Montana Statewide Angling Pressure Report).

\section{Lake Management Status:}

Management of Lower Thompson Lake commenced in 1930 when 150,000 cutthroat trout were planted. Between 1930 and 1992, various stocking options were exercised and generally reflected hatchery sources of fish and angler preferences (Table 4). Early inventories of the lake showed native species assemblages that included westslope cutthroat trout, bull trout, mountain whitefish, northern squawfish, largescale suckers, longnose suckers, and redside shiners (bull trout apparently existed at very low levels and have not been found in recent inventories).

By 1953, unauthorized introductions established populations of largemouth bass (which currently account for most of the fishing pressure in the lake), yellow perch, and pumpkinseeds in the lake system. Northem pike were illegally introduced to Upper Thompson Lake prior to 1965 and are self-sustaining and expanding their range. A few northern pike have been reported in Lower Thompson Lake. The long-term status of this species is uncertain.

Between 1954 and 1959, FWP attempted a partial eradication program to reduce yellow perch populations. Several yellow perch spawning and rearing areas in Lower Thompson Lake were poisoned to create more space for cutthroat trout. In addition, FWP liberalized whitefish daily and possession limits for the same reason. The program failed and was discontinued after 1959.

Lower Thompson Lake was also planted with kokanee in 1951 and 1952. These plants, along with kokanee plants in Middle Thompson Lake and Upper Thompson Lake, were likely the ancestors of the kokanee population that exists today in Middle Thompson Lake. In the mid1980s, soon after Flathead Lake, Whitefish Lake, and McGregor Lake kokanee populations 
crashed, anglers expressed a desire to expand and enhance other kokanee populations. In 1986, Lower Thompson Lake was added to the stocking schedule to receive 100,000 kokanee annually. To date, there is no indication that a kokanee population has been established in Lower Thompson Lake, nor does it appear that the kokanee planted each year survive in the lake in substantial numbers. FWP is monitoring the plants to determine if the stocked kokanee support the Middle Thompson Lake kokanee population.

Between 1990 and 1994, FWP planted brown trout in Lower Thompson Lake in an attempt to add a new trout to the fishery. Brown trout plants were established to create the opportunity to capture a rare (rare in Region 1) and possible trophy trout. In addition, brown trout can be highly piscivorous and Lower Thompson Lake contains high densities of potential prey (yellow perch, northern squawfish, pumpkinseeds). Brown trout currently exist in the Thompson River and Clark Fork River, so the addition of this species does not threaten the integrity of the downstream populations. To date, there is no indication that a brown trout population is established in Lower Thompson Lake, and catches are rarely reported.

Currently most angling is directed toward largemouth bass and trout. Rainbow trout provide both a summer and winter fishery. Trout catch rates are low but steady and some anglers specialize in pursuing trophy trout (greater than 10 pounds). Catch rates on yellow perch are high but only a very small percentage of the perch are considered to be of keeping size (greater than eight inches). Spearing was banned on the lake in the 1970s to discourage poaching. Trout anglers are restricted to 5 trout daily, only one trout longer than 22 inches. This regulation was established in an attempt to protect the trophy trout fishery. Bass anglers are restricted to only 1 bass daily, minimum length of 22 inches from May 15 to June 30, to protect spawning bass while still providing the opportunity to harvest a trophy bass.

\section{Management Concerns:}

1. Yellow perch and pumpkinseed densities are high enough to make successful rainbow/cutthroat trout stocking difficult. In addition, the yellow perch are stunting and do not provide a desirable fishery.

2. Brown trout are popular in other areas of the state. Unauthorized plants from an established population in Lower Thompson Lake could lead to management problems with native species in other regional waters, especially those with bull trout.

3. A suitable kokanee population has not been established in Lower Thompson Lake, although stocking may contribute to the Middle Thompson Lake kokanee population.

4. Northern pike, which exist in large numbers in Upper Thompson Lake, have not been found in appreciable numbers in Lower Thompson Lake. If northern pike become established, successful stocking of trout would be more difficult. 
5. Any exotic species planted in the Thompson Lake complex can potentially escape to the Clark Fork River system.

\section{Breferred Management Option:}

Management options considered included current management and stocking of kokanee, brown trout, and rainbow trout, discontinue trout and salmon stocking and manage for warmwater species, adjusting trout stocking rates, and investigating methods of perch control. There were 203 comments on the Thompson lakes fisheries.

Under the preferred management options, the Thompson lakes would be managed as a two-tiered fishery to include both warmwater and coldwater species (bass, and rainbow trout and kokanee, respectively). The salmonid fishery would be monitored to determine success of stocking. Brown trout stocking would cease. Stocking of kokanee would continue in Lower Thompson Lake until FWP can determine the contribution of wild versus stocked fish to the population, at which time stocking rates might be adjusted. FWP would initiate a comprehensive largemouth bass genetic survey to determine future stocking needs. FWP would initiate structure enhancement for largemouth bass for Lower, Middle, and Upper Thompson lakes and monitor the effects of structures on population trends. No structures would be placed so as to affect trolling for kokanee. Regulation on the take of kokanee would be considered to enhance catch rates and salmon densities. Rainbow trout stocking would remain at current levels and retired rainbow trout broodstock might be added to the lakes as they become available. 


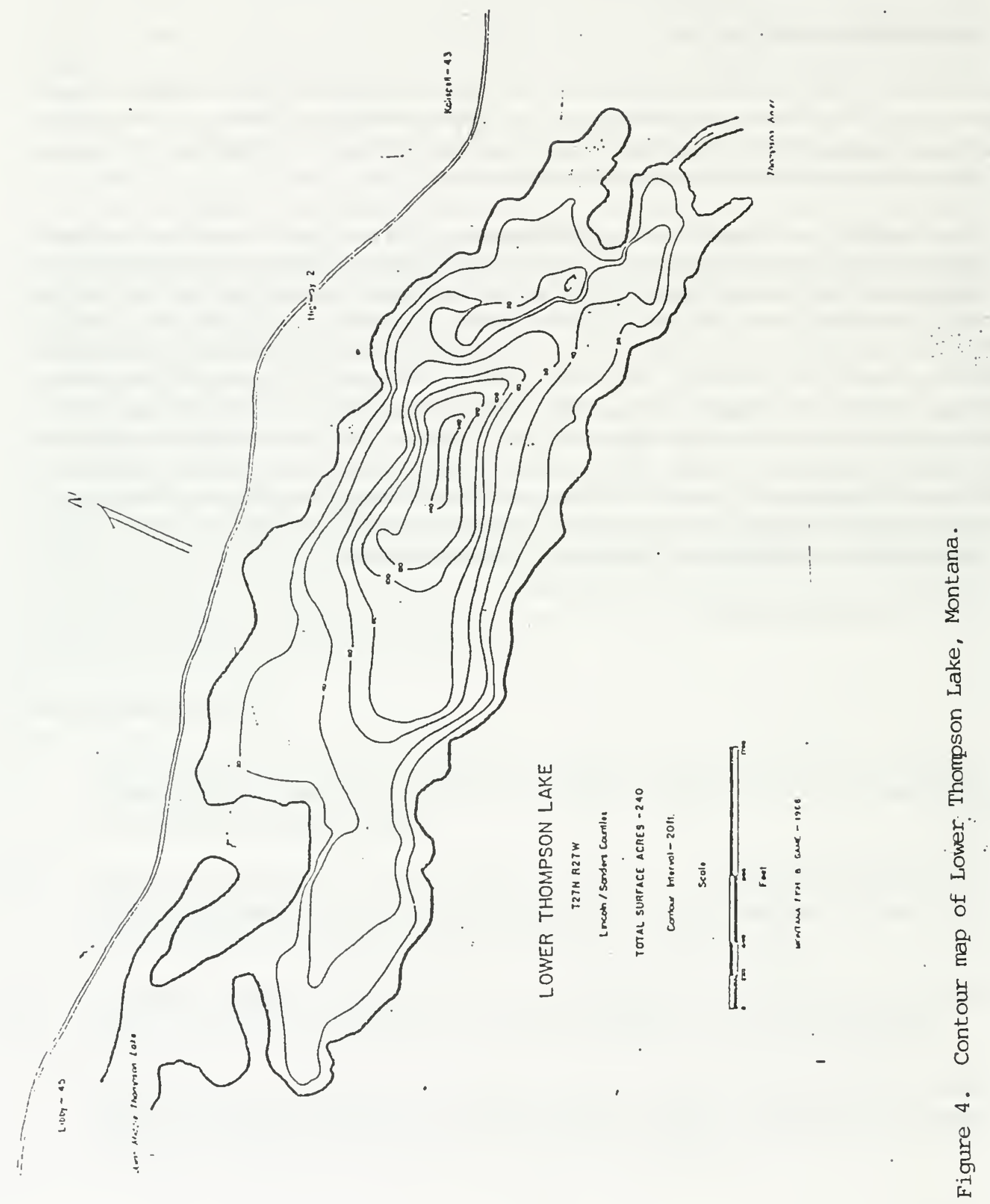


Table 4. Historic planting of Lower Thompson Lake, 1930-1994.

\begin{tabular}{|c|c|c|c|c|c|c|}
\hline \multirow[b]{2}{*}{ Yoar } & \multicolumn{6}{|c|}{ Number of Fish Planted } \\
\hline & $\begin{array}{l}\text { Cutthroat } \\
\text { Trout }\end{array}$ & Rainbow Trout & Brook Trout & $\begin{array}{l}\text { Xokbunes } \\
\text { Salmon: }\end{array}$ & $\begin{array}{l}\text { Weetslope } \\
\text { Cutthroast Trout }\end{array}$ & Brown Trout \\
\hline 1930 & 150,000 & & & & & \\
\hline 1941 & 6,900 & & & & & \\
\hline 1942 & 8,720 & & & & & \\
\hline 1943 & 8,800 & & & & & \\
\hline 1944 & 3,500 & & & & & \\
\hline 1945 & 5,960 & & & & & 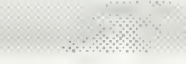 \\
\hline 1946 & 4,200 & 6,680 & & & & \\
\hline 1949 & & & 8,000 & & 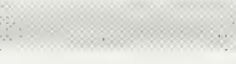 & 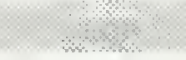 \\
\hline 1951 & & & & 64,000 & & \\
\hline 1952 & $y^{2}$ & 3,000 & & 90,135 & & \\
\hline 1954 & 121,800 & & & & & \\
\hline 1955 & 125,000 & & & & & \\
\hline 1956 & 120,960 & & & & & \\
\hline 1957 & 120,224 & 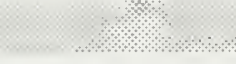 & & & & \\
\hline 1958 & 120,006 & & & & & \\
\hline 1959 & 120,320 & : : & & -. & & \\
\hline 1976 & 20,124 & & & & & \\
\hline 1977 & & 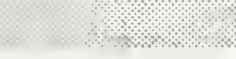 & & & 37,158 & \\
\hline 1978 & & & & & 15,021 & \\
\hline 1979 & & 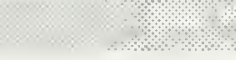 & & & 16,218 & \\
\hline 1980 & & & & & 15,000 & \\
\hline 1981 & & ? & . & & 15,000 & \\
\hline 1982 & & & & & 15,208 & \\
\hline 1983 & & 13,137 & & & & \\
\hline 1984 & & 19,910 & & & & \\
\hline 1985 & & 20,014 & & & & \\
\hline 1986 & 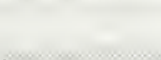 & 23,004 & & 100,000 & & \\
\hline 1987 & & 20,065 & & & & \\
\hline 1988 & & 19,993 & & & & \\
\hline 1989 & & 18,014 & & & & \\
\hline 1990 & & 20,018 & & 100,000 & & 2,712 \\
\hline 1991 & & . & & 100,000 & $\therefore$ & 2,559 \\
\hline 1992 & & 20,586 & & & & 2,513 \\
\hline 1993 & & 20,000 & & 100,000 & & 2,500 \\
\hline 1994 & & 20,000 & & 50,000 & & 2,500 \\
\hline
\end{tabular}




\section{MIDDLE THOMPSON LAKE}

\section{Lake Description:}

Middle Thompson Lake is a large, relatively deep lake. It is the middle lake in the TCL. Middle Thompson Lake receives water from Upper Thompson Lake and several small tributaries and flows to the Thompson River and Clark Fork River through Lower Thompson Lake. The lake has a maximum depth of 160 feet and has a surface area of 602 acres (Figure 5). Between March 1, 1993 and February 28, 1994, FWP estimated that as many as 5,379 anglers, of which 94 percent were Montana residents, fished at Middle Thompson Lake (Montana Statewide Angling Pressure Report).

\section{Lake Management Status:}

Management of Middle Thompson Lake commenced in 1936 when 72,500 rainbow trout and 15,000 cutthroat trout were planted (Table 5). Between 1936 and 1992, various stocking options were attempted that generally reflected stock availability and angler preferences with some notable exceptions. By 1953, rainbow trout, cutthroat trout (probably Yellowstone cutthroat trout), and brook trout populations were established over remnant native westslope cutthroat and bull trout, and over mountain whitefish, northern squawfish, largescale sucker, longnose sucker, and redside shiner populations.

In addition, unauthorized plants have established largemouth bass, yellow perch, and pumpkinseeds in the Thompson lakes chain. Northern pike were first found in 1965 in Upper Thompson Lake, and exist at relatively low levels in Middle Thompson Lake. Lake trout are periodically captured in the lake and are most likely the result of unauthorized plants from nearby McGregor Lake and/or migratory movement from McGregor Lake through McGregor Creek and the Thompson River. It appears that the native gamefish populations have been effectively replaced by exotic species from both authorized and unauthorized introductions.

Kokanee salmon were established in Middle Thompson Lake through a series of plants in Upper Thompson, Middle Thompson, and Lower Thompson Lakes between 1951 and 1953, and again in 1963. The kokanee introductions were successful in establishing a self-reproducing kokanee population. Kokanee have not been planted in the lake since 1963, although it may be possible that kokanee stocked in Lower Thompson Lake since 1986 may be supplementing the Middle Thompson Lake population. The kokanee spawn in late October along the shoreline at depths of 5 to 40 feet.

FWP has monitored kokanee populations by gillnetting during spawning runs since 1968. In that time, mature kokanee have ranged in size from mean lengths of 11 inches in 1968 to 18.3 inches in 1988 (Table 6). Anglers have complained about decreasing catch rates for kokanee in recent years. 


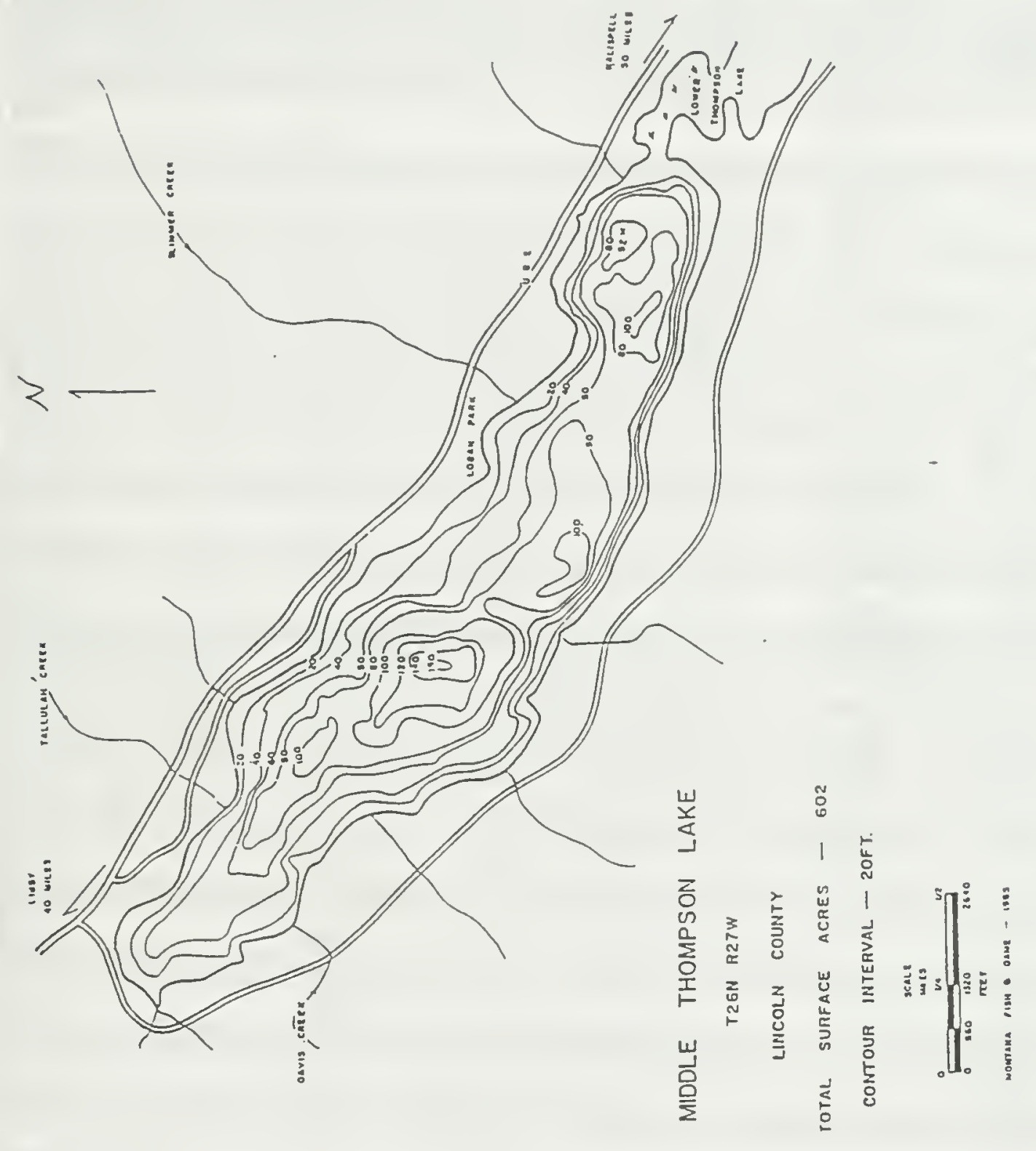

定

造

음

हृ.

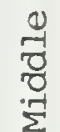

4

है

is

号

光
范
U

เi

है 
Table 5. Historic planting of Middle Thompson Lake, 1936-1994.

\begin{tabular}{|c|c|c|c|c|c|c|c|}
\hline \multirow[b]{2}{*}{ Year } & \multicolumn{7}{|c|}{ Number of Fish Planted } \\
\hline & $\begin{array}{l}\text { Raimbow } \\
\text { Trout }\end{array}$ & $\begin{array}{c}\text { Cutthroat } \\
\text { Trout }\end{array}$ & $\begin{array}{l}\text { Brook } \\
\text { Troat }\end{array}$ & $\begin{array}{l}\text { Kolcane- } \\
\text { Salmon }\end{array}$ & $\begin{array}{l}\text { Westslopo } \\
\text { Cuthroat Trout }\end{array}$ & $\begin{array}{l}\text { Browa } \\
\text { Trout }\end{array}$ & $\begin{array}{l}\text { Largomanth } \\
\text { Bass }\end{array}$ \\
\hline 1936 & 72,500 & 15,000 & & & & & \\
\hline 1941 & & 2,600 & & & & & \\
\hline 1942 & & 8,677 & & & & & \\
\hline 1943 & & 10,300 & & & & & \\
\hline 1944 & & 6,540 & & & & & \\
\hline 1945 & & 5,800 & & & & & \\
\hline 1946 & & 4,200 & 2,500 & & & & \\
\hline 1947. & & & 29,000 & & & & \\
\hline 1948 & & & 4,000 & & & & \\
\hline 1949 & & & 8,000 & (n) & & & \\
\hline 1951 & & 50,000 & & 119,000 & & & \\
\hline 1952 & 6,000 & 25,000 & & 74,375 & & & \\
\hline 1954 & & 181,440 & & & & & \\
\hline 1955 & & 180,000 & & & & & \\
\hline 1956 & & 181,440 & & & & & \\
\hline 1957 & & 180,008 & & & & & \\
\hline 1958 & & 180,218 & & & & & \\
\hline 1959 & & 181,760 & & & x- & & \\
\hline 1963 & & & & 103,408 & & & \\
\hline 1968 & & 6,468 & & & & & Fi \\
\hline 1969 & & 16,665 & & & & & \\
\hline 1971 & 24,160 & $x^{2}$ & & & & 好 & - \\
\hline 1972 & & 35,000 & & & & & \\
\hline 1976 & & 30,006 & & & & & \\
\hline 1977 & & & & & 39,560 & & \\
\hline 1978 & & & & & 16,320 & & \\
\hline 1979 & & & & & 17,839 & & \\
\hline 1980 & & & & & 16,000 & & \\
\hline 1981 & & & & & 14,991 & & \\
\hline 1982 & 15,055 & & & & & & \\
\hline 1983 & 33,333 & & & & & & \\
\hline 1984 & 30,354 & & & & & & \\
\hline 1985 & 30,012 & & & & & & \\
\hline 1986 & 30,085 & & & & & & \\
\hline 1987 & 30,013 & & & & & & \\
\hline 1988 & 30,000 & & & & & & \\
\hline 1989 & 27,021 & & & & & & \\
\hline 1990 & 29,848 & & & & & 2,712 & $4 \%$ \\
\hline 1991 & 30,005 & & & & & 2,559 & 32,600 \\
\hline 1992 & 31,988 & & & & & 2,513 & \\
\hline 1993 & 30,000 & & & & & 2,500 & \\
\hline 1994 & 30,000 & & & & & 2,500 & \\
\hline
\end{tabular}


Table 6. Summary of spawning run gill-net sets for kokanee in Middle Thompson Lake, 1968-1994.

\begin{tabular}{|c|c|c|c|c|c|c|}
\hline \multirow[b]{2}{*}{ Your } & \multicolumn{3}{|c|}{ Male Kolonee } & \multicolumn{3}{|c|}{ Formale Kolkanee } \\
\hline & $\begin{array}{l}\text { Number } \\
\text { Menarined }\end{array}$ & $\begin{array}{l}\text { Moan } \\
\text { Leneth }\end{array}$ & Rango & $\begin{array}{l}\text { Number } \\
\text { Meaizured }\end{array}$ & $\begin{array}{l}\text { Mean } \\
\text { Length }\end{array}$ & Range \\
\hline 1968 & $\begin{array}{r}97 \\
8\end{array}$ & $\begin{array}{l}11.4 \\
18.2\end{array}$ & & $\begin{array}{r}40 \\
1\end{array}$ & $\begin{array}{l}11.0 \\
21.5\end{array}$ & \\
\hline 1969 & 5 & 12.3 & 4. & 5 & 12.0 & \\
\hline 1970 & 108 & 13.1 & & 52 & 12.8 & \\
\hline 1971 & 64 & 13.8 & $11.5-17.8$ & 15 & 13.0 & $10.8-14.7$ \\
\hline 1972 & 37. & 13.1 & $9.0-13.9$ & 15 & 12.8 & $12.2-13.3$ \\
\hline 1973 & 66 & 13.7 & $12.1-15.4$ & 58 & 13.1 & $11.5-14.1$ \\
\hline 1974 & 69 & 12.8 & $11.8-14.5$ & 30 & 12.5 & $11.8-13.3$ \\
\hline 1975 & 100 & 12.8 & 11.9 .13 .9 & 96 & 12.4 & $11.5-13.2$ \\
\hline 1976 & 46 & 13.6 & $12.4-14.8$ & 29 & 13.2 & $12.4-14.0$ \\
\hline 1977 & 61 & 14.3 & $13.0-15.8$ & 49 & 13.9 & $12.6-17.9$ \\
\hline 1978 & 86 & 13.7 & $9.8-15.8$ & 66 & 13.2 & $11.6-14.3$ \\
\hline 1979 & 28 & 13.1 & $10.5-14.2$ & 18 & 12.4 & $11.8-13.2$ \\
\hline 1980 & 36 & 12.8 & $11.9-13.8$ & 26 & 12.4 & $10.8-13.6$ \\
\hline 1981 & $\begin{array}{r}51 \\
3\end{array}$ & $\begin{array}{l}12.9 \\
16.6\end{array}$ & $11.5-13.8$ & $\begin{array}{r}20 \\
5\end{array}$ & $\begin{array}{l}12.5 \\
16.6\end{array}$ & 11.414 .0 \\
\hline 1982 & 82 & 14.2 & $10.4-19.0$ & 45 & 13.6 & $12.5-17.9$ \\
\hline 1983 & 32 & 13.7 & $10.7-15.5$ & 24 & 12.8 & $11.5-15.0$ \\
\hline 1984 & 72 & 13.0 & $11.7-15.3$ & 65 & 12.6 & $11.6-14.5$ \\
\hline 1985 & 6 & 13.0 & $12.3-13.4$ & 15 & 12.4 & $12.0-13.8$ \\
\hline 1986 & 14 & 13.4 & $12.9-15.2$ & 15 & 12.8 & $12.4-13.4$ \\
\hline 1987. & \multicolumn{3}{|c|}{ NO DATA } & \multicolumn{3}{|c|}{ NO DATA } \\
\hline 1988 & 11 & 18.3 & $16.6-19.5$ & 10 & 17.0 & $15.6-17.8$ \\
\hline 1989 & \multicolumn{3}{|c|}{ NO DATA } & \% & NO DA & $8 \ldots$ \\
\hline 1990 & 37 & 16.2 & $15.1-17.4$ & 29 & 15.7 & $14.7-16.6$ \\
\hline 1991 & \multicolumn{3}{|c|}{ NO DATA } & \multicolumn{3}{|c|}{ NO DATA } \\
\hline 1992 & 25 & 15.3 & $13.7-19.4$ & 25 & 14.8 & $13.6-16.5$ \\
\hline 1993 & 25 & 17.1 & $15.4-18.4$ & 25 & 16.4 & $15.6-18.4$ \\
\hline 1994 & 51 & 19.3 & $17.3-20.8$ & 34 & 18.1 & $17.3-19.3$ \\
\hline
\end{tabular}

The rainbow trout fishery has been maintained by hatchery stocking over a remnant wild population. Gillnetting and creel surveys indicate the average length of rainbow trout is about 14 inches with 10 pound or larger rainbows occasionally found. Brown trout have been planted in Middle Thompson Lake from 1992 to present for the same reasons as Lower Thompson Lake. 
Largemouth bass, introduced through unauthorized plants are well established in the Thompson Lake chain. In recent years, the Thompson lakes have been popular for bass fishing tournaments. The Northwest Montana Bassmaster Club has placed artificial habitat structures in Middle Thompson Lake to enhance bass populations. Bass are able to avoid gill nets (due to their body form and agility) so FWP uses catch per effort from bass tournament contestants to identify trends in the bass population (Table 7).

Table 7. Results from bass toumaments held on Middle Thompson Lake, Montana 1989 - 1993.

\begin{tabular}{||ccccccc|}
\hline $\begin{array}{c}\text { Tourney } \\
\text { Date }\end{array}$ & $\begin{array}{c}\text { Number of } \\
\text { Anglers }\end{array}$ & $\begin{array}{c}\text { Bass } \\
<=12 \\
\text { lnches }\end{array}$ & $\begin{array}{c}\text { Bass } \\
>12 \\
\text { Inches }\end{array}$ & $\begin{array}{c}\text { Total } \\
\text { Fishing } \\
\text { Hours }\end{array}$ & $\begin{array}{c}\text { Number } \\
\text { Caught per } \\
\text { Hour }\end{array}$ & $\begin{array}{c}\text { Mean } \\
\text { Length } \\
\text { (in.) }\end{array}$ \\
\hline $06 / 17 / 89$ & 53 & & 59 & 901 & 0.065 & 14.1 \\
$06 / 30 / 91$ & 36 & 222 & 161 & 576 & 0.66 & \\
$07 / 19 / 92$ & 34 & & 147 & & & \\
\hline
\end{tabular}

In 1990, starch gel electrophoresis done on bass populations in northwest Montana indicated bass populations were not very diverse genetically (they appeared to be nearly clones of one another). Low genetic diversity is a problem because it can lead to complications such as low fecundity (egg production) and low survival. In 1991, FWP attempted to increase genetic diversity by hatchery supplementation. FWP stocked 32,600 fingerling bass in Middle Thompson Lake in hopes that when they mature, they will randomly breed with the wild population and introduce new genetics into the population.

Currently most angling is directed toward kokanee and largemouth bass. Kokanee provide both a summer and winter fishery. Trout catch rates are low but steady and some anglers specialize in pursuing trophy trout (greater than 10 pounds). Catch rates on yellow perch are high but only a very small percentage of the perch are considered to be of keeping size (greater than eight inches). Spearing was banned on the lake in the 1970 s to discourage poaching. Trout anglers are restricted to 5 trout daily, only one trout longer than 22 inches. This regulation was established in an attempt to protect the trophy trout fishery and to spread harvest among more anglers. Bass anglers are restricted to only 1 bass daily, minimum length of 22 inches from May 15 to June 30, to protect spawning bass and to spread harvest throughout the year.

\section{Management Concerns:}

1. As with all TCL lakes, yellow perch, pumpkinseeds, and northern pike introductions can make successful stocking of rainbow trout difficult. 
2. The contribution of kokanee salmon planted in Lower Thompson Lake to the Middle Thompson Lake population is unknown at this time. Kokanee catch rates are lower than anglers would prefer.

3. FWP is not certain the current largemouth bass population can withstand the dramatically increased angling pressure seen in the last decade. The population will probably persist but possibly at much lower densities.

4. The effects of brown trout stocking on existing fish populations are currently unknown. It is also unknown if stocked brown trout can survive in the current TCL system.

5. Because of the lake's topography, shallow water habitat and cover for bass is limited.

6. Any exotic species planted in the Thompson Lake complex can potentially escape to the Clark Fork River system.

\section{Breferred Mansement Option:}

Management options considered included current management and stocking levels, discontinue stocking, increasing salmon densities, and artificial bass structure placement. There were 203 comments on the Thompson lakes fisheries.

Under the preferred management option, the Thompson lakes would be managed as a two-tiered fishery to include both warmwater and coldwater species (bass, and rainbow trout and kokanee, respectively). The salmonid fishery would be monitored to determine success of stocking. Brown trout stocking would cease. Stocking of kokanee would continue in Lower Thompson Lake until FWP can determine the contribution of wild versus stocked fish to the population at which time stocking rates might be adjusted. FWP would initiate a comprehensive largemouth bass genetic survey to determine future stocking needs. FWP would initiate structure enhancement for largemouth bass for Lower, Middle, and Upper Thompson lakes and monitor the effects of structures on population trends. No structures would be placed so as to affect trolling for kokanee. Regulation on the take of kokanee would be considered to enhance catch rates and salmon densities. Rainbow trout stocking would remain at current levels and retired rainbow trout broodstock might be added to the lakes as they become available.

\section{UPPER THOMPSON LAKE}

\section{Lake Description:}

Upper Thompson Lake is a medium-sized lake with connections to the Thompson River and Clark Fork River through Middle and Lower Thompson lakes. It is comprised of a series of three relatively shallow basins ( 90 percent of depth less than 10 feet) separated by narrow shallow 
channels. It has a maximum depth of 100 feet and has a surface area of 232 acres (Figure 6). Between March 1, 1993 and February 28, 1994, FWP estimated that as many as 3,885 anglers, of which 96 percent were Montana residents, fished at Upper Thompson Lake (Montana Statewide Angling Pressure Report).

\section{Lake Management Status:}

Management of Upper Thompson Lake commenced in 1936 when 25,000 cutthroat trout (probably Yellowstone cutthroats) were planted (Table 8). Stocking was sporadic and generally reflected stock availability and angler preferences. Kokanee salmon that were stocked in the lake in 1944, 1952,1953 , and 1963 probably contributed to the current wild population that exists in Middle Thompson Lake.

Yellow perch, pumpkinseeds, largemouth bass, and in the 1960s northern pike were illegally introduced to Upper Thompson Lake and currently dominate the fishery. Illegally stocked smallmouth bass were documented in the 1980s but appear to be in very low numbers. Upper Thompson Lake was surveyed with gill nets in 1992. The non-game species pumpkinseeds (6.4/net) and yellow perch (8.6/net) dominated the catch; northern pike $(1.2 /$ net) were of average size and condition. Crayfish, are also in quite high densities (23.5/net) in Upper Thompson Lake.

FWP ceased all stocking of trout and salmon in 1983 (with the exception of 1992 and 1994 when approximately 400 broodstock rainbow trout were stocked) because of poor survival. The lake is currently scheduled to receive 500 Duncan strain (kamloops) rainbow trout per year beginning in 1995.

Currently most angling is directed toward northern pike and perch both in spring/summer and winter ice fishery. Largemouth bass for many years were the mainstay of the fishery for Upper Thompson Lake. Bass are still popular but their numbers have decreased as northern pike have increased. In the past, stocked trout produced a fair trout fishery with occasional trophy trout prior to northern pike introductions.

Catch rates on yellow perch are high but only a small percentage of the perch are considered to be of keeping size (greater than eight inches). Spearing was banned on the lake in the 1970s to discourage poaching. Trout anglers are restricted to 5 trout daily, only one trout longer than 22 inches. This regulation was established in an attempt to protect the trophy trout fishery. Bass anglers are restricted to only 1 bass daily, minimum length of 22 inches from May 15 to June 30, to protect spawning bass and spread harvest throughout the year. 


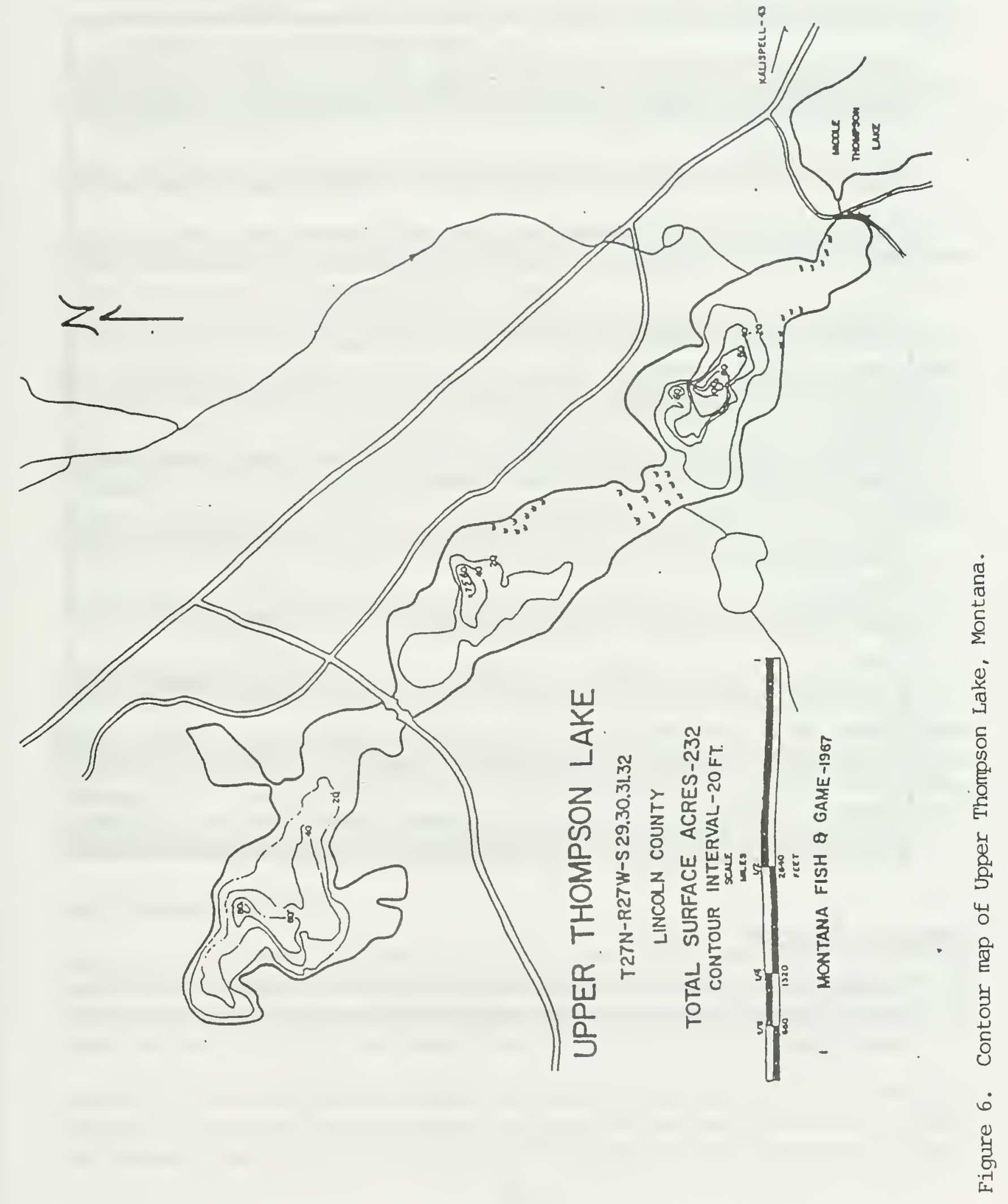


Table 8. Historic planting of Upper Thompson Lake, 1936-1994.

\begin{tabular}{|c|c|c|c|c|c|c|}
\hline \multicolumn{7}{|c|}{ Number of Fish Planted } \\
\hline Yoer. & $\begin{array}{l}\text { Cutthroat } \\
\text { Trout }\end{array}$ & $\begin{array}{l}\text { Brook } \\
\text { Trout }\end{array}$ & $\begin{array}{l}\text { Kolkanos } \\
\text { Salmon }\end{array}$ & $\begin{array}{l}\text { Rainbow } \\
\text { Trout }\end{array}$ & $\begin{array}{l}\text { Woutslope } \\
\text { Cuthroat Trout }\end{array}$ & $\begin{array}{l}\text { Rainbow Trout } \\
\text { (brood stock) }\end{array}$ \\
\hline 1936 & 25,000 & & & & & \\
\hline 1941 & 1,200 & & & & & \\
\hline 1942 & & 2,200 & & & & \\
\hline 1943 & & 4,000 & & & . & \\
\hline 1944 & & & 22,500 & & & \\
\hline 1946 & & 5,200 & & & & \\
\hline 1948 & & 2,000 & & & & \\
\hline 1951 & & 400 & & & & \\
\hline 1952 & & & 90,135 & 3,000 & & \\
\hline 1953 & $\sqrt[3]{3}$ & & 50,752 & 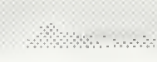 & in & $\ldots$ \\
\hline 1963 & & & 103,408 & & & \\
\hline 1969 & 5,040 & & & & . & \\
\hline 1976 & & & & & 4,989 & \\
\hline 1977 & & & & & 6,002 & \\
\hline 1980 & & & & & 5,000 & \\
\hline 1981 & & & & & 4,995 & \\
\hline 1982 & & & & 5,018 & & \\
\hline 1983 & & & & 3,998 & & \\
\hline 1992 & & & & & & 407 \\
\hline 1994 & & & & & & 400 \\
\hline
\end{tabular}

\section{Management Concerns:}

1. Because of high predator densities (primarily northern pike), stocking of trout is very difficult. Trout would be susceptible to northern pike predation at all but larger sizes (>16 inches). 
2. The geography of Upper Thompson Lake (three basins that flow through narrow, shallow channels and 90 percent of the lake less than 10 feet deep) make any fish (especially trout) vulnerable to northem pike predation.

3. Any exotic species planted in the Thompson Lake complex can potentially escape to the Clark Fork River.

\section{Breferred Management Option:}

Management options considered included current management for pike/bass/perch, rainbow trout stocking, catchable rainbow trout stocking, and artificial structure placement for bass. There were 203 comments on the Thompson lakes chain.

Under the preferred management option, Upper Thompson Lake would be managed as a twotiered fishery with primary emphasis on warmwater fish (pike, bass) while maintaining opportunities for trout, as feasible. FWP would initiate a comprehensive largemouth bass genetic survey to determine future stocking needs. FWP would initiate structure enhancement for largemouth bass. Large rainbow trout might be added to the lake as they become available. FWP will propose allowing spearing of northern pike through the ice on Upper Thompson Lake to provide some additional control on this illegally introduced fish and to provide an additional angling experience in the TCL.

\section{RAINBOW LAKE}

\section{Lake Description:}

Rainbow Lake is a small closed-basin lake north of Upper Thompson Lake and east of Crystal Lake. The maximum depth of Rainbow Lake is unknown (probably less than 75 feet) and it has a surface area of 20 acres. Between March 1, 1993 and February 29, 1994, FWP estimated that as many as 395 anglers, of which 100 percent were Montana residents, fished at Rainbow Lake (Montana Statewide Angling Pressure Report).

\section{Lake Management Status:}

Management of Rainbow Lake commenced in 1932 when 37,000 rainbow trout were planted (Table 9). Though several other species have been planted, management of Rainbow Lake has been primarily for rainbow trout. Unauthorized plants of largemouth bass and pumpkinseeds occurred at least by the 1940s, and illegal yellow perch introductions soon followed.

Gillnetting in 1992 indicated that rainbow trout planted in the previous year were relatively abundant (5.0 per net) and in good condition, although no holdover trout (greater than 12 inches) were captured. Yellow perch are very abundant in Rainbow Lake (28 per net) and undoubtedly 
affect rainbow populations adversely through competition and, to a lesser extent, predation. Crayfish currently exist in the lake and may be the result of unauthorized plants. Largemouth bass were not captured in the nets but were known to be quite abundant in the past.

Rainbow Lake is totally surrounded by Plum Creek Timberland property and that property is scheduled to go on sale in 1997. Sale of the lake to a different owner may preclude management for a public fishery.

\section{Management Concerns:}

Yellow perch populations make successful stocking of rainbow trout very difficult.

\section{Preferred Management Option:}

Management options considered included current stocking levels, chemical rehab, to increase bass levels to control yellow perch and to manage as a bass/perch fishery. Rainbow Lake received 48 comments.

Under the preferred management option, Rainbow Lake would be managed as a two-tiered fishery to include bass and trout. Stocking rates of trout would be adjusted through monitoring to maximize catch rates. Experimental stocking of largemouth and smallmouth bass could commence. FWP would monitor the success of the program and make adjustments through the adaptive management provision. Regulations for bass could include the spawning closure (May 15 through June 30; one bass daily and in possession, 22 inch minimum). All activities proposed are provisional on acquiring a permanent access agreement with Plum Creek Timber Company as the lake is entirely within Plum Creek lands. 
Table 9. Historic planting of Rainbow Lake, 1932-1994.

\begin{tabular}{|c|c|c|c|c|c|}
\hline \multirow[b]{2}{*}{ Yoar } & \multicolumn{5}{|c|}{ Number of Fish Planted } \\
\hline & $\begin{array}{l}\text { Reinbow } \\
\text { Trout }\end{array}$ & $\begin{array}{l}\text { Arctic } \\
\text { Oreyling }\end{array}$ & $\begin{array}{l}\text { Coho } \\
\text { Salmon }\end{array}$ & $\begin{array}{l}\text { Brook } \\
\text { Trout }\end{array}$ & $\begin{array}{l}\text { Cuthroast } \\
\text { Trout }\end{array}$ \\
\hline 1932 & 37,000 & & & & \\
\hline 1934 & 13,250 & & & & \\
\hline 1936 & & 120,00 & & & \\
\hline 1938 & & & 21,0 & & \\
\hline 1939 & & & 21,0 & & \\
\hline 1940 & & & 25,0 & & \\
\hline 1942 & 620 & & & & \\
\hline 1943 & 3,000 & . & $=$ & & \\
\hline 1944 & 2,800 & & & & \\
\hline 1945 & 435 & & & & \\
\hline 1946 & 3,320 & & & & \\
\hline 1948 & 10,000 & 2) & & & \\
\hline 1949 & 40,000 & & 24,00 & & \\
\hline 1950 & 10,000 & & & & \\
\hline 1951 & 788 & & & 1,640 & \\
\hline 1952 & 6,000 & 2 & & 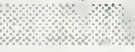 & \\
\hline 1953 & 15,200 & & & & \\
\hline 1954 & 2,750 & & & & \\
\hline 1957 & & & & & 2,640 \\
\hline 1959 & & & & & 3,000 \\
\hline 1965 & 4,070 & & & & \\
\hline 1968 & 2,040 & . & ? & 2. & x) \\
\hline 1971 & 2,000 & & & & \\
\hline 1972 & 3,000 & 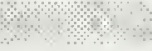 & +4 & 8 & 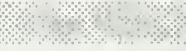 \\
\hline 1973 & 2,000 & & & & \\
\hline 1975 & 1,995 &.. & & 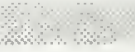 & \\
\hline 1977 & 2,207 & & & & \\
\hline 1978 & 2,016 & 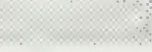 & & & \\
\hline 1979 & 2,014 & & & & \\
\hline 1980 & 2,013 & 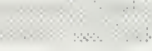 & & & \\
\hline 1981 & 2,010 & & & & \\
\hline 1982 & 2,218 & & & & \\
\hline 1983 & 2,006 & & & & \\
\hline 1984 & 2,012 & $\because$ & 10 & 2. & \\
\hline 1985 & 2,036 & & & & \\
\hline 1986 & 2,012 & & & & \\
\hline 1987 & 2,023 & & & & \\
\hline 1988 & 1,719 & & & & \\
\hline 1989 & 1,814 & & & & \\
\hline 1990 & 2,000 & : & & & \\
\hline 1991 & 2,014 & & & & \\
\hline 1992 & 2,000 & & & & \\
\hline 1993 & 2,000 & & & & \\
\hline 1994 & 2,000 & & & & \\
\hline
\end{tabular}




\section{CRYSTAL AND LAVON LAKES}

\section{Lake Descriptions:}

Because they are connected through a passable channel, Crystal Lake and Lavon Lake will be considered as a single management unit for the purposes of this document. Crystal Lake is a medium sized lake connected to Lavon Lake through a 20 feet wide by 4 feet deep channel. The lakes are a closed basin.

Crystal Lake has a maximum depth of 154 feet and has a surface area of 178 acres (Figure 7). Lavon Lake is a small, relatively deep lake. It has a maximum depth of 91 feet and has a surface area of 17 acres. Between March 1, 1993 and February 28, 1994, FWP estimated that as many as 2,868 anglers, of which 84 percent were residents, fished at Crystal and Lavon Lakes (Montana Statewide Angling Pressure Report).

\section{Lakes Management Status:}

Management of Crystal Lake and Lavon Lake commenced in 1924, when Crystal Lake was stocked with 100,000 chinook salmon and Lavon Lake was stocked with bass and sunfish (Table 10). Angling success was marginal and several other species were tried including rainbow trout, cutthroat trout, brook trout, coho salmon, and arctic grayling. The lakes already had strong populations of largescale suckers. Coho salmon plants were relatively successful through the 1950 s but sucker numbers continued to dominate gill net catches. The Libby Rod and Gun Club offered to run traps in the spring to capture spawning suckers that traveled through the channel.

FWP decided to rehabilitate the lakes and in August of 1960 both lakes were treated with Toxaphene. Because of lake depths, slow mixing and toxicity of Toxaphene, Lavon Lake would not support fish until 1962 and Crystal Lake until 1964. In 1962, Lavon was planted with an unknown number of kokanee salmon and when Crystal Lake was planted with kokanee and rainbow trout in 1964, Lavon Lake was officially removed from the stocking list although it continued to receive a portion of Crystal Lake plants. The lakes remained "clean" of unwanted species until the early 1970s when unauthorized plants established yellow perch and pumpkinseed populations in both lakes.

A self-reproducing population of kokanee salmon was established from plants between 1964 to 1967. Between 1967 and 1976, angling was excellent for large kokanee and FWP planted only rainbow trout in Crystal Lake. In 1976, FWP initiated kokanee stocking for Crystal Lake to enhance fishing opportunities. At the same time FWP began monitoring kokanee populations in Crystal Lake (Table 11). Kokanee plants continued through the 1970s and early 1980s with very good success. 


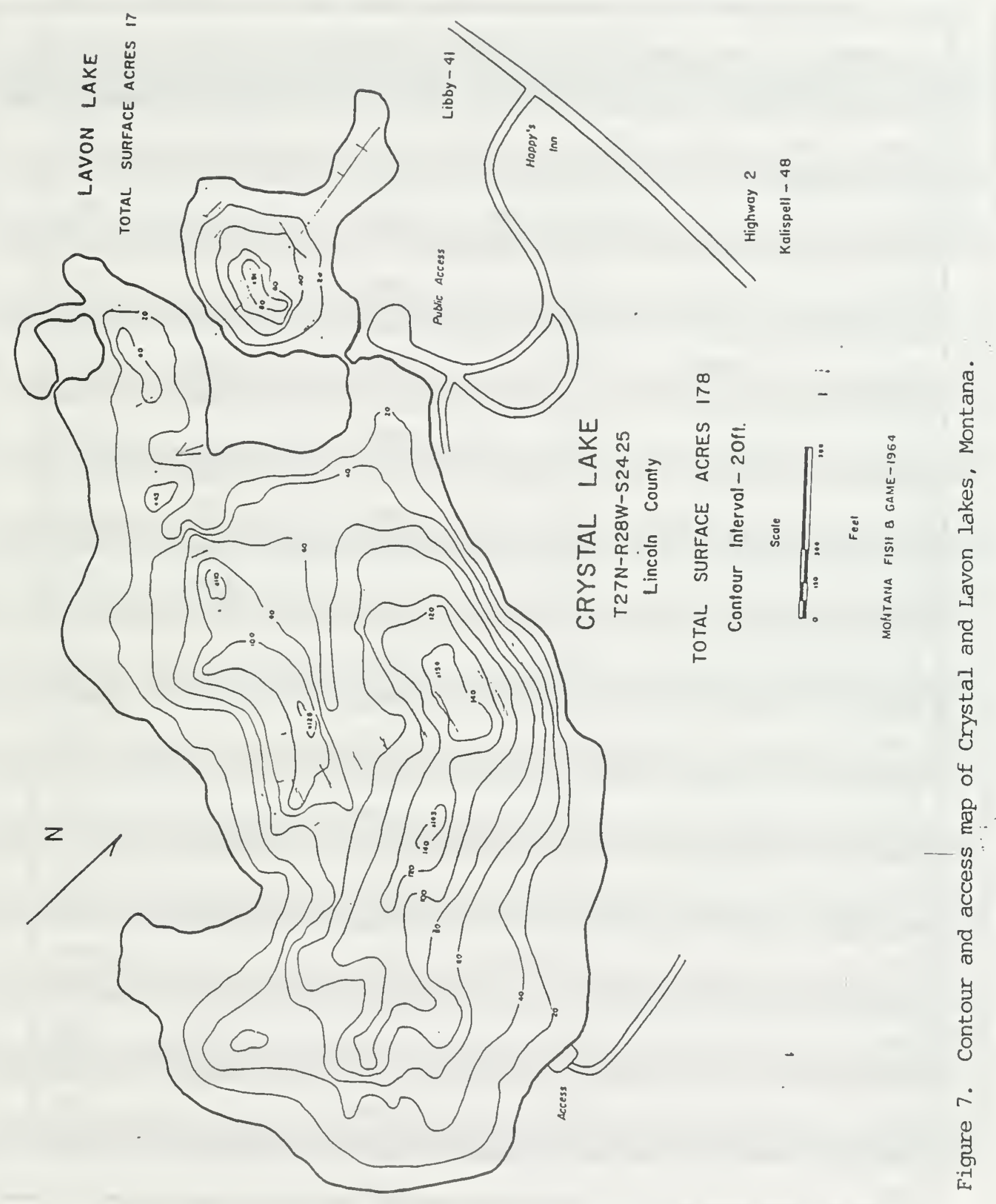


Table 10. Historic planting of Crystal and Lavon lakes, 1924-1994.

\begin{tabular}{|c|c|c|c|c|c|c|c|c|c|}
\hline \multicolumn{10}{|c|}{ Number of Fish Planted } \\
\hline Year & $\begin{array}{l}\text { Chinook } \\
\text { Sulmoon }\end{array}$ & Bass & Sunfish & $\begin{array}{l}\text { Cutthroat } \\
\text { Trout }\end{array}$ & $\begin{array}{l}\text { Rainbow } \\
\text { Trout }\end{array}$ & $\begin{array}{l}\text { Brook } \\
\text { Troout }\end{array}$ & $\begin{array}{l}\text { Coho } \\
\text { Salmom }\end{array}$ & $\begin{array}{c}\text { Arctic } \\
\text { Grayling }\end{array}$ & $\begin{array}{l}\text { Kolanese } \\
\text { Selmusa }\end{array}$ \\
\hline 1924 & 100,000 & 3,000 & 200 & & & & & & \\
\hline 1925 & 35,000 & & (1) & 30,000 & $\therefore \ldots$ & & & & \\
\hline 1926 & & & 40,000 & 80,000 & 50,000 & & & & \\
\hline 1927 & 17,440 & $\approx$ & & & & 12,000 & & & \\
\hline 1929 & & & & & 165,000 & & & & \\
\hline 1931 & & $4: 2$ & ?: & 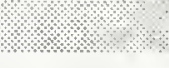 & 148,000 & & & & \\
\hline 1932 & & 90,000 & & & 5,000 & & 9,000 & & \\
\hline 1933 & & & & & 10,000 & & 31,456 & & \\
\hline 1934 & & & & & 47,000 & & & & \\
\hline 1935 & & & & & & & 40,000 & & \\
\hline 1938 & & & & & 2,500 & & 21,000 & & \\
\hline 1940 & & & & & 1,000 & & 25,000 & & \\
\hline 1941 & & & & & & & 40,000 & & \\
\hline 1942 & & & & & 3,120 & & & & \\
\hline 1943 & & & & & 7,800 & & & & \\
\hline 1944 & & 2. & & & 5,702 & & & & \\
\hline 1945 & & & & & 4,195 & & & & \\
\hline 1946 & & & & & 13,280 & & & & \\
\hline 1948 & & & & & 750 & & & & \\
\hline 1949 & & & & & 35,000 & & 44,000 & & \\
\hline 1950 & & & & & 30,000 & & & & \\
\hline 1951. & & & & & 1,280 & & 5,460 & & \\
\hline 1952 & & & & 107,400 & 9,000 & & & 374,000 & \\
\hline 1953 & & & & & 6,000 & & 14,400 & 187,000 & \\
\hline 1954 & & & & & & & 31,310 & & \\
\hline 1955 & & & & & & & 27,160 & & \\
\hline 1956 & & & & & 24,060 & & & & \\
\hline 1958 & & & & & 23,232 & & & & \\
\hline 1959 & & & & & 24,000 & & & & \\
\hline
\end{tabular}


Table 10. Continued.

\begin{tabular}{|c|c|c|c|c|c|c|c|c|c|}
\hline \multicolumn{10}{|c|}{ Number of Fish Planted } \\
\hline Year & $\begin{array}{l}\text { Chinook } \\
\text { Salmon }\end{array}$ & Rass & Sunfish & $\begin{array}{l}\text { Cutthroat } \\
\text { Trout }\end{array}$ & $\begin{array}{c}\text { Rainbow } \\
\text { Trout }\end{array}$ & $\begin{array}{l}\text { Brook } \\
\text { Tront }\end{array}$ & $\begin{array}{l}\text { Coho } \\
\text { Salmon } \\
\end{array}$ & $\begin{array}{l}\text { Arctic } \\
\text { Grayling }\end{array}$ & $\begin{array}{l}\text { Xolowioe } \\
\text { Salmon }\end{array}$ \\
\hline 1964 & & & & 78,120 & & & & & 352,724 \\
\hline 1965 & & & & & 78,000 & & : & & 118,320 \\
\hline 1966 & & & & & 97,931 & & & & 302,74 \\
\hline 1967 & & & & & & & & & 273,408 \\
\hline 1969 & & & & & 5,000 & & & & \\
\hline 1971 & & & & & 5,056 & & 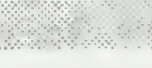 & & \\
\hline 1972 & & & & & 18,000 & & & & \\
\hline 1974 & & & & & 5,015 & & & & \\
\hline 1975 & & & & & 5,033 & & & & \\
\hline 1976 & & & & & 5,033 & & & & 90,000 \\
\hline 1977 & & & & & 7,168 & & & & 100,000 \\
\hline 1978 & & & & & 7,000 & & & & 50,000 \\
\hline 1979 & & & & & 7,038 & & & & 50,000 \\
\hline 1980 & & & & & 7,029 & & & & 50,000 \\
\hline 1981 & & & & & 7,517 & & & & \\
\hline 1982 & & & & & 7,708 & & & & 50,000 \\
\hline 1983 & & & & & 7,027 & & & & 50,000 \\
\hline 1984 & & & & & 7,072 & & & & 49,982 \\
\hline 1985 & & & & & 10,017 & & & & \\
\hline 1986 & & & & & 10,014 & & & & 50,000 \\
\hline 1987 & & & & & 8,793 & & & & 50,000 \\
\hline 1988 & & & & & 8,007 & & 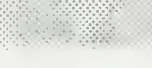 & & $1 \%$ \\
\hline 1989 & & & & & 8,000 & & & & 50,479 \\
\hline 1990 & & & & & 9,019 & & & & 100,000 \\
\hline 1991 & & & & & 8,017 & & & & 96,030 \\
\hline 1992 & & & & & 8,028 & 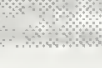 & in. & & 132,96 \\
\hline 1993 & & & & & 8,000 & & & & 54,000 \\
\hline 1994 & & & & & 8,000 & & & & 50,000 \\
\hline
\end{tabular}


Table 11. Summary of kokanee gillnetting and hatchery stocking rates for Crystal Lake, Montana, 1975-1993.

\begin{tabular}{|c|c|c|c|c|}
\hline \multirow[b]{2}{*}{ Yaar } & \multicolumn{2}{|c|}{$\begin{array}{c}\text { Mean Lengths (Ranges) } \\
\text { of Spawning Adults }\end{array}$} & \multicolumn{2}{|c|}{$\begin{array}{l}\text { Hatchery Plants } \\
\text { and } \\
\text { Hatchery Origin }\end{array}$} \\
\hline & Male & Founale & Koknoee Salmon & Raimbow Trat \\
\hline 1975 & $18.1(17.2-19.8)$ & $17.6(15.8-18.4)$ & - & 4,995 (A) \\
\hline 1976 & 17.1 & .17 .6 & $90,000(S)$ & $5,033(A)$ \\
\hline 1977 & $17.3(12.4-20.1)$ & $18.0(14.9-21.6)$ & $100,000(S)$ & 7,168 (A) \\
\hline 1978 & $16.5(15.2-19.5)$ & $15.6(11.0-20.5)$ & $50,000(S)$ & $7,000(\mathrm{~A})$ \\
\hline 1979 & $17.5(13.9-18.5)$ & $17.2(16.6-18.1)$ & $50,000(\mathrm{~S})$ & $7,038(A)$ \\
\hline 1980 & $\therefore 19.2$ & 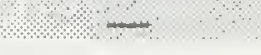 & $50,000(S)$ & $7,029(A)$ \\
\hline 1981 & not sampled & - & - & $7,517(\mathrm{~A})$ \\
\hline 1982 & not sempoled & 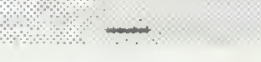 & $50,000(S)$ & $7,708(\mathrm{~A})$ \\
\hline 1983. & not sampled & - & $50,000(\mathrm{MS})$ & 7,027 (A) \\
\hline 1984. & not sumpled & $+\div$ & $49,982(\mathrm{MS})$ & $7,072(A)$ \\
\hline 1985 & $15.1(12.0-16.5)$ & $16.2(12.3-18.5)$ & - & 10,017 (A) \\
\hline 1986 & $14.4(13.6-16.6)$ & $14.0(13.415 .2)$ & $50,000(S)$ & $10,014(\mathrm{~A})$ \\
\hline 1987 & - & - & $50,000(S)$ & 8,739 (A) \\
\hline 1988. & $18.2(17.7-20.5)$ & $17.9(16.9-19.0$ & - & $8,007(A)$ \\
\hline 1989 & not sampled & - & $50,000(\mathrm{MS})$ & 8,000 (A) \\
\hline 1990 & $\begin{array}{c}9.6(8.8-11.2) \\
14.2(12.8-17.1)\end{array}$ & $\begin{array}{c}9.3(8.8-9.7) \\
14.1(12.7-17.1)\end{array}$ & $100,000(\mathrm{MS})$ & $9,000(\mathrm{~A})$ \\
\hline 1991 & $9.0(8.2-9.8)$ & $9.1(8.3-9.7)$ & $100,000(\mathrm{MS})$ & $8,000(\mathrm{~A})$ \\
\hline 1992 & $9.5(8.7-10.4)$ & $9.2(8.7-10.3)$ & $132,000(S)$ & 8,000 (A) \\
\hline 1993 & $10.7(9.8-11.4)$ & $11.0(10.4-11.8)$ & $50,000(S)$ & 8,000 (A) \\
\hline 1994 & $15.7(15.4-17.2)$ & $14.4(13.4-15.5)$ & $50,000(S)$ & $8,000(A)$ \\
\hline
\end{tabular}

A = Arlee Hatchery $M S=$ Murray Springs Hatchery $S=$ Somers Hatchery

In the mid to late 1980s, Crystal Lake was stocked annually with about 50,000 kokanee (Table 10). In 1988, kokanee eggs were scarce and Crystal Lake was not stocked. To make up for the loss, 100,000 to 132,000 kokanee were planted between 1990 and 1992 and unfortunately kokanee lengths dropped from 16 to 20 inches in 1988 to 9 to 14 inches in 1990. Two possible impacts could have occurred. First, kokanee are known to exhibit inverse density dependent growth (as numbers of kokanee increase, their size decreases to compensate for less space and food). 
It is possible that by doubling the stocking level, Crystal Lake kokanee reacted by slowing their growth. Second, it is possible that the source of eggs from one or more of those years were from a genetic stock that is slower growing and spawns at a younger age (normally kokanee spawn as three-year-olds in Crystal Lake, during the time of smaller kokanee, most were spawning as twoyear-olds). In 1993, FWP returned the kokanee plant in Crystal Lake to 50,000 per year (historic levels). Lengths of kokanee have since increased from means of 9.2 to 9.5 inches to 10.7 to 11.0 inches. In 1994, kokanee were back near historic lengths.

Currently, anglers fish Crystal Lake and Lavon Lake primarily for kokanee, rainbow trout, and perch. Kokanee are showing signs of increasing lengths and rainbow trout have a good average size and produce good to average catch rates with an occasional large (greater than five pounds) trout caught. There are some bass in the lake and fishing pressure is pretty light. Yellow perch produce both a spring/summer and winter ice fishery for fair numbers and good sizes ( 8 to 12 inches).

\section{Management Concerns:}

1. Yellow perch populations are currently at densities high enough to make successful stocking of kokanee difficult. In addition, the significance of competition for food between kokanee and yellow perch is unknown.

2. Kokanee sizes were 4 to 7 inches below historic lengths, although lengths are increasing, stocking rates appear to impact kokanee growth.

3. There apparently is some natural reproduction by kokanee in Crystal Lake. The level is currently unknown, making stocking level estimates difficult.

4. Lavon Lake is known to at least partially winterkill. Nutrients from septic systems may artificially enrich the lakes and aggravate this problem.

\section{Breferred Management Option:}

Management options presented included current stocking levels, adjustment of hatchery kokanee plants, and introduction of kamloops (Duncan) rainbow. The lakes received 60 comments.

Under the preferred management option, Crystal/Lavon lakes would be management primarily as a kokanee salmon fishery. Through monitoring, FWP would identify wild versus hatchery contribution to the population and through adaptive management would adjust stocking rates accordingly. Arlee rainbow trout stocking would continue at current levels and FWP would monitor rainbow trout and adjust stocking densities through the adaptive management provision. 


\section{BOOTJACK LAKE}

\section{Lake Descciption:}

Bootjack Lake is a small closed-basin lake near Happy's Inn. Its maximum depth is approximately 41 feet and it has a surface area of approximately 12 acres. Between March 1, 1993 and February 28, 1994, FWP estimated that as many as 426 anglers of which 60 percent were Montana residents, fished at Bootjack Lake (Montana Statewide Angling Pressure Report).

\section{Lake Management Status:}

Management of Bootjack Lake commenced in 1932 when 8,000 rainbow fry were planted (Table 12). Between 1932 and 1992, various species including coho salmon, arctic grayling, and cutthroat trout have been planted in the lake. Unauthorized plants of bass and pumpkinseeds during the $1950 \mathrm{~s}$ and $1960 \mathrm{~s}$ made management difficult. In the past, high concentrations of amphipods (freshwater shrimp) produced large trout (up to 20 inches). Bootjack lake is known to winterkill during years of long ice duration and heavy snow cover. It appears that winterkills were substantial and included all species.

Gill-net sets from 1992 indicated good numbers (5 per net set) and relatively good growth for rainbow trout in Bootjack Lake (approximately 3.5 to 4.0 inches in the first two years). The largest trout were 3 years old, 15 inches in length and nearly 1 pound. Pumpkinseeds were also found in the gill nets. Pumpkinseeds have existed for several years in the lake at fairly low concentrations. Pumpkinseeds could become a problem due to their high reproductive potential and ability to stunt (FWP has found that trout planting success decreases dramatically as panfish populations increase).

Crayfish were found in the gill nets in fairly high concentrations (17 per net set). Crayfish are relatively new to the lake and may be the result of unauthorized plants. The significance of crayfish to the management of the lake is currently unknown, although rainbow trout are known to feed on crayfish in other systems. A possible result of crayfish and pumpkinseed introductions is the apparent lack of amphipods in the lake. In the past, densities of amphipod were described as "dripping off the gill nets" and in "buckets". In 1992, no amphipods were observed in the water or in fish stomachs. The lake is currently known for providing moderate to good fishing for small to medium sized trout.

\section{Management Concerns:}

Increased nongame fish populations (pumpkinseeds) may make successful stocking of rainbow trout difficult. 
Table 12. Historic planting of Bootjack Lake, 1932-1994.

\begin{tabular}{|c|c|c|c|c|}
\hline \multirow[b]{2}{*}{ Your } & \multicolumn{4}{|c|}{ Numbor of Fish Plantod } \\
\hline & Rnimbow Trout & Arctic Gruyling & Coho Salmon & Cutthroat Trout \\
\hline 1932 & 8,000 & & & \\
\hline 1937. & & 74,000 & 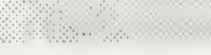 & \\
\hline 1939 & & & 1,000 & \\
\hline 1952 & 7,000 & & & \\
\hline 1954 & & & & 5,060 \\
\hline 1955 & & & & 2,500 \\
\hline 1956 & & & & 3,000 \\
\hline 1957 & & & & 24,200 \\
\hline 1958 & & & & 2,160 \\
\hline 1959 & & & & 2,000 \\
\hline 1961 & 2,146 & & & \\
\hline 1962 & 1,999 & & & \\
\hline 1964 & 4,115 & & & \\
\hline 1965 & 4,000 & & & $\therefore$ \\
\hline 1966 & & & & 411 \\
\hline 1969 & & & & 5,045 \\
\hline 1972 & & & & 4,060 \\
\hline 1973 & & & & 2,000 \\
\hline 1976 & & & & 2,003 \\
\hline 1978 & & & & 1,927 \\
\hline 1979 & & & & 1,995 \\
\hline 1980 & & & : & 2,508 \\
\hline 1981 & & & & 2,520 \\
\hline 1982 & 2,520 & & & \\
\hline 1983 & 2,513 & & & \\
\hline 1984 & 2,502 & & & \\
\hline 1985 & 4,038 & & & \\
\hline 1987 & & & & 2,003 \\
\hline 1988 & 3,003 & & & \\
\hline 1989 & . . & & & 1,968 \\
\hline 1992 & 3,024 & & & \\
\hline 1994 & 3,000 & & & \\
\hline
\end{tabular}




\section{Prefecred Management Option:}

Management options considered included maintaining current stocking rates and management, chemical rehab, and converting the lake to a trophy or large lake trout management lake through regulations. Bootjack received 50 comments.

Under the preferred management option, Bootjack Lake would be rehabilitated as funding becomes available and rainbow and/or cutthroat or brook trout would be reintroduced at historic levels. Through monitoring and adaptive management, the opportunity to manage the lake as trophy lake would be assessed after the rehabilitation.

\section{TOPLESS LAKE}

\section{Lake Description:}

Topless Lake is a small closed-basin lake east of Horseshoe Lake and south of Bootjack Lake. It has a maximum depth of 24 feet and has a surface area of approximately 9 acres. Between March 1, 1993 and February 28, 1994, FWP estimated that as many as 121 anglers of which 100 percent were Montana residents, fished at Topless Lake (Montana Statewide Angling Pressure Report).

\section{Lake Management Status:}

Management of Topless Lake commenced in 1969 when initial gill-net surveys produced no fish. FWP decided Topless Lake represented an opportunity to support a limited number of anglers and planted 10,545 cutthroat trout (Table 13). Since that time, FWP has managed the lake to receive 2,000 to 3,000 trout (species depended on availability) on a two-year rotating basis to maximize growth rates.

Between 1969 and 1983, illegal introductions established populations of black bullheads and pumpkinseeds in Topless Lake. Crayfish, which were not common to TCL have also been found in relatively high numbers and are likely the result of unauthorized stocking. Gillnetting in 1992 produced only one rainbow trout and high numbers of pumpkinseeds (17.5 per net) and black bullheads (5.0 per net).

\section{Management Concerns:}

1. High numbers of pumpkinseeds and black bullheads make successful stocking of rainbow or cutthroat trout difficult due to competition and predation.

2. Topless Lake is known to winter kill occasionally. 
3. Because of proximity of small and large lakes, FWP cannot ensure that undesirable species won't be replanted in Topless Lake if it is chemically rehabilitated.

\section{Preferred Management Option:}

Management options considered included maintaining the current stocking rates and management, chemical rehab, or converting to a warmwater fishery (bass, pike) to provide a different fishery and for biological control of pumpkinseeds and bullheads. Topless Lake received 48 comments.

Under the preferred management option, Topless Lake would be rehabilitated as funding becomes available (preferably at the same time as Bootjack Lake) and rainbow and either cutthroat trout or brook trout would be reintroduced at historic levels. Through monitoring and adaptive management, the fishery would be assessed and adjusted as necessary.

Table 13. Historic planting of Topless Lake, 1969-1994.

\begin{tabular}{|c|c|c|c|c|c|}
\hline \multirow[b]{2}{*}{ Year } & \multicolumn{5}{|c|}{ Number of Fish Planted } \\
\hline & $\begin{array}{l}\text { Cutthrout } \\
\text { Trout }\end{array}$ & $\begin{array}{l}\text { Arctic } \\
\text { Grayling }\end{array}$ & $\begin{array}{l}\text { Westslopo } \\
\text { Cutthroat Trout }\end{array}$ & $\begin{array}{c}\text { Rainbow } \\
\text { Trout }\end{array}$ & $\begin{array}{c}\text { Kamloope } \\
\text { Raumbow Trout }\end{array}$ \\
\hline 1969 & 10,545 & & & & \\
\hline 1970 & & 5,000 & & & \\
\hline 1972 & & & 6,000 & & \\
\hline 1974 & & & 2,016 & 8 & \\
\hline 1976 & & & 4,989 & & \\
\hline 1978 & & & 4,700 & & \\
\hline 1979 & & & 4,970 & & \\
\hline 1981 & & & 3,024 & & \\
\hline 1983 & & & & 2,554 & \\
\hline 1985 & & & & 2,036 & \\
\hline 1987 & & & & 2,023 & \\
\hline 1989 & & & 2,016 & \% & $\ldots$ \\
\hline 1990 & & & & & 2,001 \\
\hline 1992 & & & & 2,030 & \\
\hline 1994 & & & & 2,000 & \\
\hline
\end{tabular}




\section{CIBID LAKE}

\section{Lake Description:}

Cibid Lake is a small closed-basin lake located southwest of Horseshoe Lake. It has a maximum depth of 60 feet and a surface area of 11 acres. Between March 1, 1993 and February 28, 1994, FWP estimated that as many as 81 anglers of which 100 percent were Montana residents, fished at Cibid Lake (Montana Statewide Angling Pressure Report).

\section{Lake Status:}

Management of Cibid Lake commenced in 1973 when initial gill-net surveys indicated that pumpkinseeds and largemouth bass had been illegally introduced to the lake. FWP initiated planting of Cibid Lake with rainbow trout in 1973 on a two-year rotating basis to maximize growth rates (Table 14). There is no natural reproduction of trout in Cibid Lake so the population is supported wholly by stocking. A 1992 gill-net survey produced rainbow from 12 to 14 inches (1.7 per net) that were in good condition relative to adjacent lakes. In addition, pumpkinseeds were captured at relatively high numbers (6.0 per net). Although no bass were captured, they probably exist at a low density.

Table 14. Historic fish stocking of Cibid Lake 1973-1994.

\begin{tabular}{|c|c|c|}
\hline Year & Species Stocked & Number Planted \\
\hline 1973 & rainbow trout & 3,000 \\
\hline 1975 & rainbow trout & 1,995 \\
\hline 1977 & rainbow trout & 1,000 \\
\hline 1981 & rainbow thout & 3,060 \\
\hline 1983 & rainbow trout & 3,429 \\
\hline 1985 & rainbow trout & 2,018 \\
\hline 1987 & rainbow trout & 2,041 \\
\hline 1989 & minhow trout & 1,814 \\
\hline 1991 & rainbow trout & 2,014 \\
\hline 1993 & rainbow trout & 2,000 \\
\hline
\end{tabular}

\section{Management Concerns:}

1. Pumpkinseeds and largemouth bass make successful stocking of rainbow and cutthroat trout difficult. 
2. Bocause of proximity of small and large lakes, FWP cannot ensure that undesirable species won't be replanted in Cibid Lake if it is rehabilitated.

\section{Brefecred Mansgement Option:}

Management actions considered included maintaining current stocking and management, chemical rehab and restock with trout, or chemical rehab, stock with trout, and manage as a trophy lake. Cibid Lake received 48 comments.

Under the preferred management option, the current rainbow stocking would continue on Cibid Lake with the addition of either cutthroat or brook trout. Rehabilitation should remain an option for the future. Fishing regulations to produce larger trout will be considered.

\section{CAD LAKE}

\section{Lake Description:}

Cad Lake is a small closed-basin lake west of Crystal Lake. It has a maximum depth of 31 feet and a surface area of approximately 4 acres. FWP did not estimate fishing pressure for Cad Lake in 1992 although angler accounts suggest that Cad Lake supports more than 50 anglers per year.

\section{Lake Management Status:}

Management of Cad Lake commenced in 1972 when approximately 4,000 cutthroat trout were planted (Table 15). There is no natural reproduction of trout in Cad Lake so the population was supported wholly by hatchery supplementation. Prior to 1972, unauthorized introductions established populations of yellow perch and pumpkinseeds.

In 1975, FWP chemically rehabilitated Cad Lake with rotenone, and in 1976 cutthroat trout were planted in the lake. Cad Lake is currently managed as a small lake fishery planted on a two-year rotating basis to maximize growth. Stocking has rotated between rainbow and westslope cutthroat trout. Stocking was switched to rainbow trout in 1990 because westslope cutthroat were in short supply at the time and rainbow trout produce a slightly larger trout.

Gillnetting in 1992 indicated that Cad Lake still has only trout in it. The population appears to be strong (12 per net) and healthy with larger trout approaching 18 inches. Cad Lake currently is the only small lake in the TCL that was rehabilitated and still shows no indications of having any unauthorized plants (Banana Lake was rehabilitated in 1992). 
Table 15. Historic fish planting in Cad Lake 1972-1994.

\begin{tabular}{|c|c|c|}
\hline Your & Species Stocked & Number Planted \\
\hline 1972 & cutthroat trout & 4,140 \\
\hline 1976 & conthroat trout & 3,010 \\
\hline 1978 & cutthroat trout & 2,000 \\
\hline 1980 & cutthroat trout & 1,501 \\
\hline 1982 & rainbow trout & 1,512 \\
\hline 1983 & rainbow trout & 1,005 \\
\hline 1984 & rainbow trout & 1,006 \\
\hline 1987 & rainbow troul & 1,027 \\
\hline 1989 & cutthroat trout & 990 \\
\hline $1990^{\circ}$ & ruinbow troul & 1,004 \\
\hline 1992 & rainbow trout & 1,532 \\
\hline 1994 & rainibow trout & 1,500 \\
\hline
\end{tabular}

\section{Management Concerns:}

1. As with all the lakes in the TCL, unauthorized introductions are a concern.

\section{Preferred Management Option:}

Management options considered included maintaining current management and stocking, consider management for a trophy trout, or switch to westslope cutthroat management. Cad Lake received 48 comments.

Under the preferred management option, current management for rainbow trout would be continued with the possible addition of cutthroat or brook trout. Fishing regulations to produce larger trout will be considered.

\section{HORSESHOE LAKE}

\section{Lake Description:}

Horseshoe Lake is a large closed-basin lake located southwest of Loon Lake and Leon Lake. Horseshoe Lake has a maximum depth of 133 feet, mean depth of 45 feet, a surface area of 160 acres (Figure 8). Between March 1, 1993 and February 28, 1994, FWP estimated that as many as 157 anglers of which 100 percent were Montana residents, fished at Horseshoe Lake (Montana Statewide Angling Pressure Report). 


\section{Lake Management Status:}

Management of Horseshoe Lake commenced in 1924 when 20,000 rainbow trout were planted (Table 10). Between 1924 and 1981, planting of the lake was sporadic and generally represented stock availability and angler preferences. Plants included coho and kokanee salmon, rainbow trout, cutthroat trout, and brook trout. Because of high rough fish populations (mainly northern squawfish and largescale suckers) planting success was marginal. In 1945 and 1950, FWP attempted to introduce bull trout and lake trout respectively, in an attempt to biologically lower rough fish populations. The experiment met with no success.

Gillnetting showed species composition in Horseshoe Lake in 1966 was northem squawfish (17 per net), largescale suckers ( 9.0 per net), longnose suckers ( 1 per net), and pumpkinseeds (1 per net); redside shiners were noted in large numbers along the shoreline. These numbers were similar to 1968 and 1973 gill-net surveys. There were no trout captured. In 1956, FWP determined that Horseshoe Lake should be rehabilitated. This was locally popular but problems with access to the lake and funding led to no action taken.

Horseshoe Lake was surveyed again in 1992 with gill nets. Rough fish populations were similar to historic levels. Duncan strain rainbow trout (kamloops) from a 1990 plant were captured at low numbers $(0.6$ per net). These trout had the lowest condition of any trout in the TCL. The trout did provide some angling opportunity, though.

\section{Management Concerns:}

1. Current angler use of Horseshoe Lake is almost non-existent; the lake is under-utilized by anglers.

2. Continued high rough fish populations (especially northern squawfish) make successful introductions of rainbow or cutthroat trout difficult to impossible.

3. Complete rehabilitation of Horseshoe Lake would require approximately 2,700 gallons of rotenone. The cost per gallon of rotenone (1994) is $\$ 30$. Including labor the cost to rehabilitate Horseshoe Lake would be approximately $\$ 85,000$.

4. There is a historic bald eagle nest on Horseshoe Lake. 


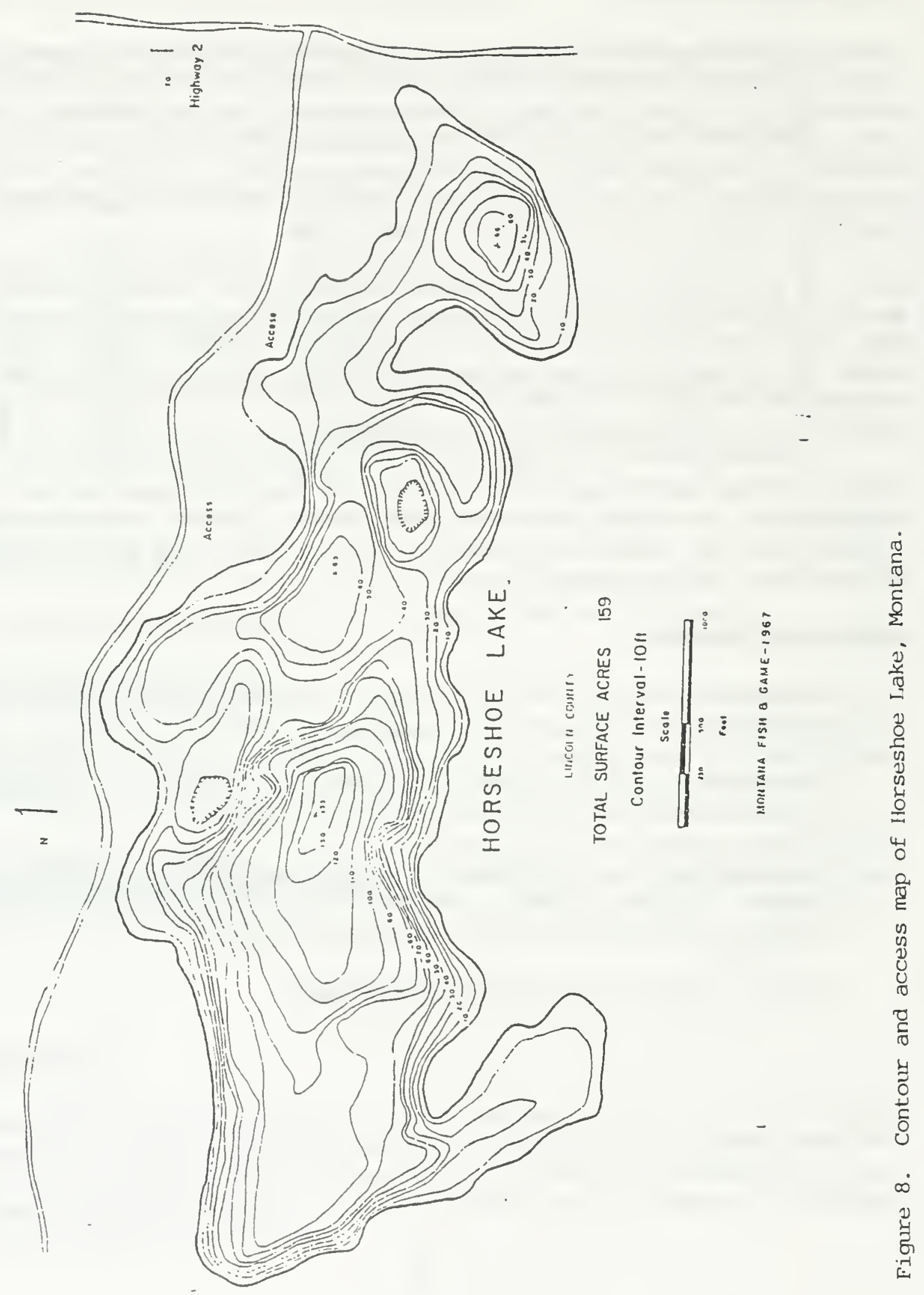




\section{Breferced Management Option:}

Management options considered included current management with no stocking, chemical rehabilitation, stocking of kamloops rainbows, and stocking of tiger muskies. Horseshoe Lake received 57 comments.

Under the preferred management option, an environmental assessment on the introduction of tiger muskie would be prepared for public comment. If approved, tiger muskie would be introduced to Horseshoe Lake to provide a biological control for the rough fish population and provide a trophy fishery. The restriction on take of tiger muskies would be the state regulation (1 fish, 30 inch minimum). If tiger muskie reduce the rough fish, rainbow trout will be introduced to the system and through monitoring and adaptive management, stocking rates will be adjusted accordingly.

Table 16. Historic planting of Horseshoe Lake, 1924-1994.

\begin{tabular}{|c|c|c|}
\hline Year & Species Stocked & Number Planted \\
\hline 1924 & rainbow trout & 20,000 \\
\hline 1932 & coho salmon & 3,675 \\
\hline 1933 & $\begin{array}{l}\text { rainbow trout } \\
\text { coho salmon }\end{array}$ & $\begin{array}{r}36,000 \\
28,800\end{array}$ \\
\hline 1935 & coho satimon & 20,000 \\
\hline 1940 & kokanee salmon & 45,000 \\
\hline 1941 & $\begin{array}{l}\text { kakanoo salinon } \\
\text { bake trout }\end{array}$ & $\begin{array}{l}41,000 \\
29,000\end{array}$ \\
\hline 1945 & bull trout & 4,900 \\
\hline 1950 & lakes trout & 11,680 \\
\hline 1952 & brook trout & 1,275 \\
\hline 1954 & cutthroast trout & 15,180 \\
\hline 1955 & cutthroat trout & 17,420 \\
\hline 1956 & curthroat trout & 22,000 \\
\hline 1957 & cutthroat trout & 15,840 \\
\hline 1958 & cutthroat trout & 15,360 \\
\hline 1959 & cutthroat trout & 16,800 \\
\hline 1981 & rainbow trout & 21,945 \\
\hline 1990 & kamloops rainbow trout & 3,136 \\
\hline
\end{tabular}




\section{LEON LAKE}

\section{Lake Description:}

Leon Lake is a small closed-basin waterbody between Loon Lake and Horseshoe Lake. Its maximum depth is 87 feet and a surface area of 22 acres (Figure 9). Between March 1, 1993 and February 28, 1994, FWP estimated that as many as 349 anglers of which 100 percent were Montana residents, fished at Leon Lake (Montana Statewide Angling Pressure Report).

\section{Lake Management Status:}

Management of Leon Lake commenced in 1932 when 5,000 rainbow trout were planted (Table 17). Between 1932 and 1969, the lake had received periodic plants of rainbow, brook, and cutthroat trout, and coho and kokanee salmon. The lake already had a population of northern squawfish, and by 1968 unauthorized plants helped to establish pumpkinseeds and largemouth bass.

In 1969, FWP determined that the lake was not providing an acceptable fishery and rehabilitated the lake with rotenone. The lake was subsequently restocked with westslope cutthroat trout.

Since the initial plant of cutthroat trout in 1970, management emphasis has shifted to rainbow trout. Currently, the Department plants 2,500 Arlee rainbow trout every other year (beginning 1992).

Loon Lake was surveyed with gill nets in 1994. Only yellow perch (57 per net) and crayfish (3 per net) were captured. Although no rainbow trout were captured, there is evidence that the lake supports a limited summer and winter trout fishery.

\section{Management Concerns:}

High rough fish numbers make successful stocking of trout species difficult.

\section{Preferred Management Option:}

Management options considered included current management with stocking of Arlee rainbow trout every other year, switching to an annual trout plant, switching to westslope cutthroat trout, chemically rehab the lake and restock with trout, and eliminate trout stocking and switch management to perch and bass. Leon Lake received 49 comments.

Under the preferred management option, Leon Lake will be managed for rainbow/cutthroat trout at this time. The stocking rates will be changed to include Arlee rainbow trout and westslope cutthroat trout on alternating years. Through monitoring and adaptive management, stocking rates will be adjusted to maximize catch rates. Rehabilitation should remain an option for the future. 


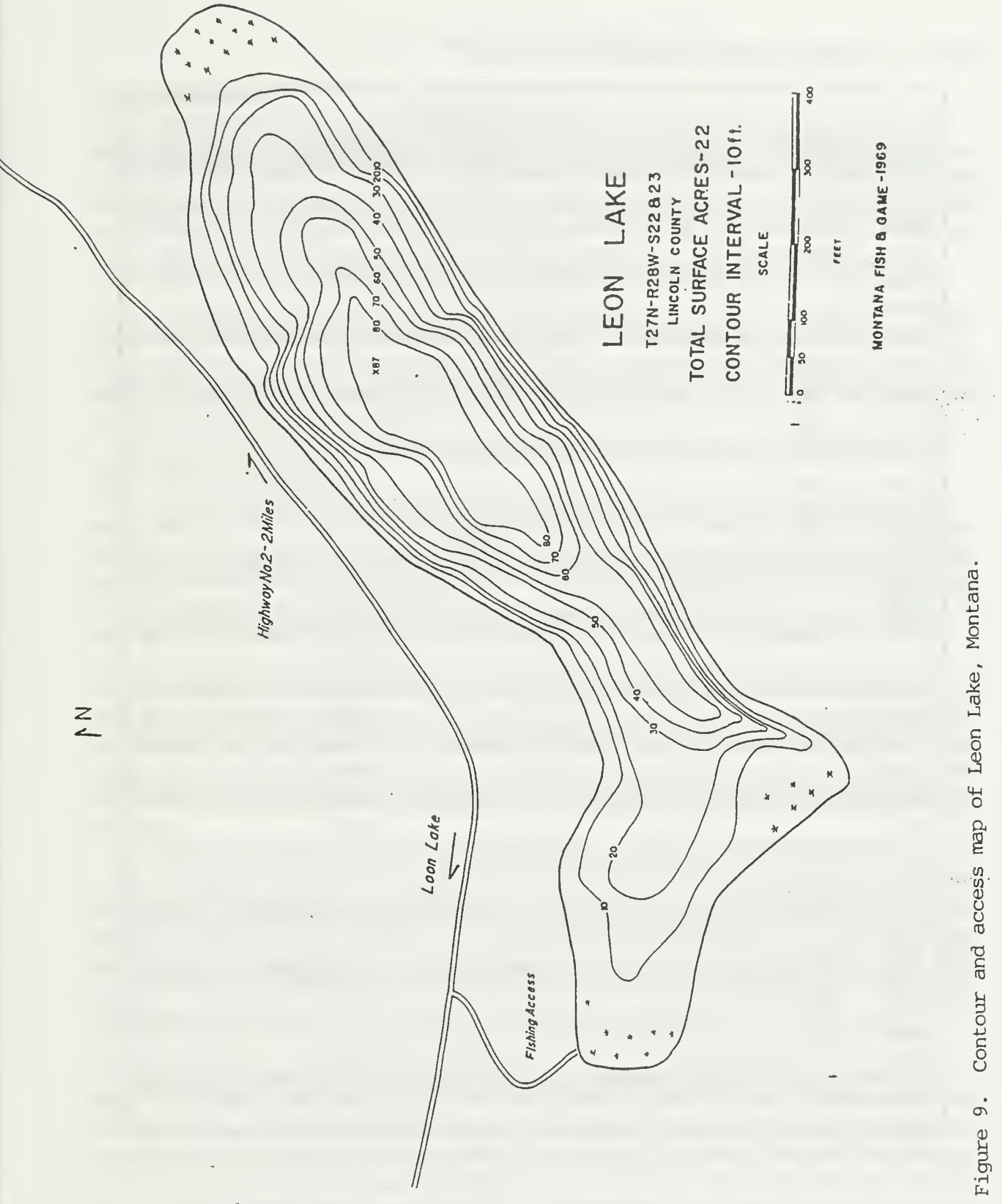


Table 17. Historic planting of Leon Lake, 1932-1994.

\begin{tabular}{|c|c|c|c|c|c|c|}
\hline & \multicolumn{6}{|c|}{ Number of Fish Planted } \\
\hline Yoar & $\begin{array}{c}\text { Rainbow } \\
\text { Trout }\end{array}$ & $\begin{array}{l}\text { Coho } \\
\text { Salmon }\end{array}$ & $\begin{array}{l}\text { Brook } \\
\text { Trout }\end{array}$ & $\begin{array}{l}\text { Kotanteo } \\
\text { Salmon }\end{array}$ & $\begin{array}{l}\text { Westslope } \\
\text { Cutthroat Trout }\end{array}$ & $\begin{array}{l}\text { Kamloops } \\
\text { Ránbow Trout }\end{array}$ \\
\hline 1932 & 5,000 & & & & & \\
\hline 1933 & & 17,300 & & & & \\
\hline 1935 & 15,000 & & & & & \\
\hline 1936 & & 8,500 & : & & & \\
\hline 1937 & & & 3,950 & & & \\
\hline 1940 & $=2$ & 25,000 & & & & \\
\hline 1942 & 3,400 & & & & & \\
\hline 1943 & 1,800 & & & & & \\
\hline 1944 & 1,500 & & & & & \\
\hline 1945 & 2,135 & & & & & \\
\hline 1946 & 3,260 & & & & & \\
\hline 1948 & 5.750 & & & 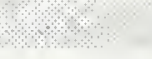 & & \\
\hline 1952 & 3,000 & & & 104,000 & & \\
\hline 1963 & & & & 49,456 & & \\
\hline 1970 & & & & & 8,400 & \\
\hline 1972 & & & & & 3,010 & \\
\hline 1973 & & & & & 5,078 & \\
\hline 1975 & 2 & & & & 5,799 & \\
\hline 1976 & & & & & 8,694 & \\
\hline 1978 & & & & & 3,760 & \\
\hline 1979 & & & & & 3,990 & \\
\hline 1980 & : & & 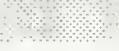 & & 4,005 & (20 \\
\hline 1981 & & & & & 3,990 & \\
\hline 1982 & 3,108 & & & & & \\
\hline 1983 & 3,016 & & & & & \\
\hline 1984 & 3,046 & . & & & & \\
\hline 1985 & 2,511 & & & & & \\
\hline 1986 & 2,521 & 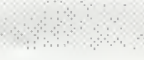 & $=$ & . & 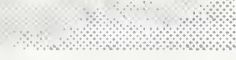 & a \\
\hline 1987 & 2,511 & & & & & \\
\hline 1988 & 2,516 & & & & 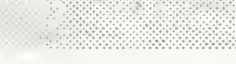 & \\
\hline 1990 & & & & & 2,490 & 3,047 \\
\hline 1992 & 2,522 & & & & & \\
\hline 1994 & 2,500 & & & & & \\
\hline
\end{tabular}




\section{LOON AND LITTLE LOON LAKES}

\section{Lake Descriptions:}

Because of their connections through the Pleasant Valley Fisher River, Loon Lake and Little Loon Lake will be considered as a single management unit for the purposes of this document. Loon Lake is a large lake south of U.S. Highway 2 and west of Horseshoe Lake. The Pleasant Valley Fisher River flows into the lake on the northeast shore and out again at the southwest shoreline. Loon Lake has a maximum depth of 114 feet and a surface area of 238 acres (Figure 10).

Little Loon Lake is a small lake downstream of Loon Lake via the Pleasant Valley Fisher River. Little Loon Lake has a maximum depth of 38 feet and a surface area of 11.6 acres (Figure 11). Between March 1, 1993 and February 28, 1994, FWP estimated that as many as 421 anglers, of which 75 percent were Montana residents, fished at Loon and Little Loon Lakes (Montana Statewide Angling Pressure Report).

\section{Lakes Management Status:}

Management of Loon and Little Loon lakes commenced in 1931 when 15,000 chinook salmon were planted (Table 18). The lakes have been planted with a variety of species since that time including rainbow trout, westslope cutthroat trout, brook trout, arctic grayling, and smallmouth bass. Gill-netting and creel surveys from the 1950s and 1960s indicated that Loon and Little Loon lakes had a wide variety of native and non-native species at one time or another.

Native to the lakes in 1956 were westslope cutthroat trout, bull trout, mountain whitefish, northern squawfish, largescale suckers, longnose suckers, and Columbia River chubs (peamouths). Also found in the lakes as the result of unauthorized plants were largemouth bass, pumpkinseeds, yellow perch, and northern pike. Despite the tremendous diversity and species makeup, Loon Lake continued to provide good to excellent fishing for bass, yellow perch, and rainbow trout into the 1980s.

Due to the high diversity of fish species, including four to six highly predacious species, and because rehabilitation was impossible due to the open system, stocking trout as a management tool was discontinued in Loon Lake in 1977. Currently the lakes are managed as a self-reproducing bass/trout/yellow perch fishery. A gill-netting survey in Loon Lake in 1992 indicated both largemouth bass and smallmouth bass and rainbow trout were relatively abundant and in good condition.

Northern squawfish and pumpkinseeds are present in high densities and bull trout apparently no longer exist in the lakes or exist at such low densities that current sampling techniques have not captured them. An additional gill-net survey conducted on Little Loon Lake in 1994 showed similar species compositions, except that rainbow trout were not captured. Currently most angling is directed toward largemouth and smallmouth bass and perch Trout catch rates are low but steady. Catch rates on yellow perch are high in spring/summer and winter but only a moderate percentage of the perch are considered to be of keeping size (greater than eight inches). Spearing was banned on the lake in the 1970 s to discourage poaching. 


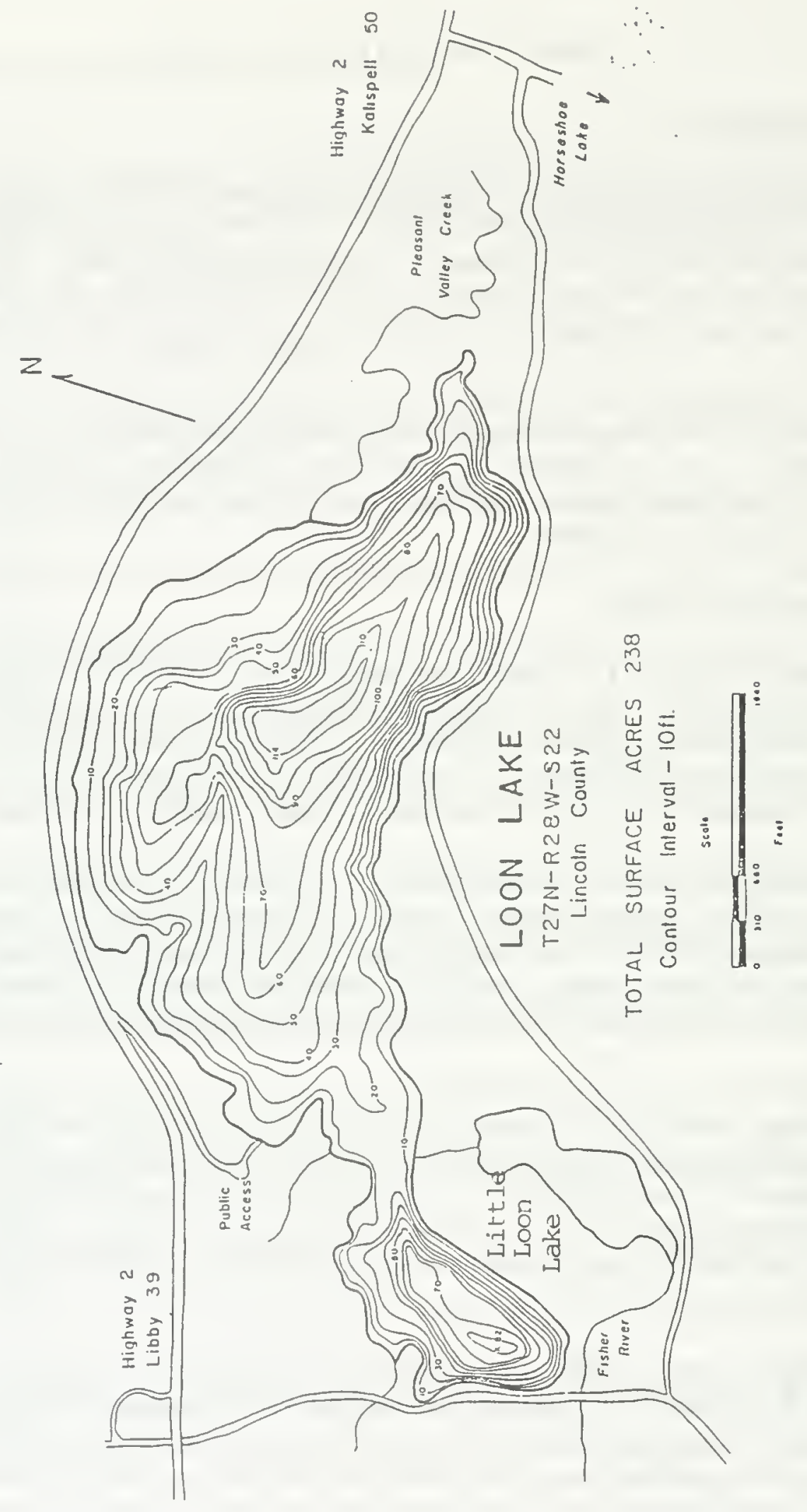

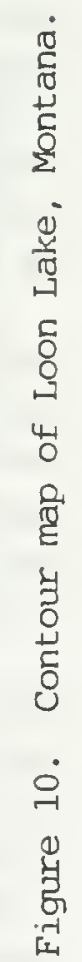




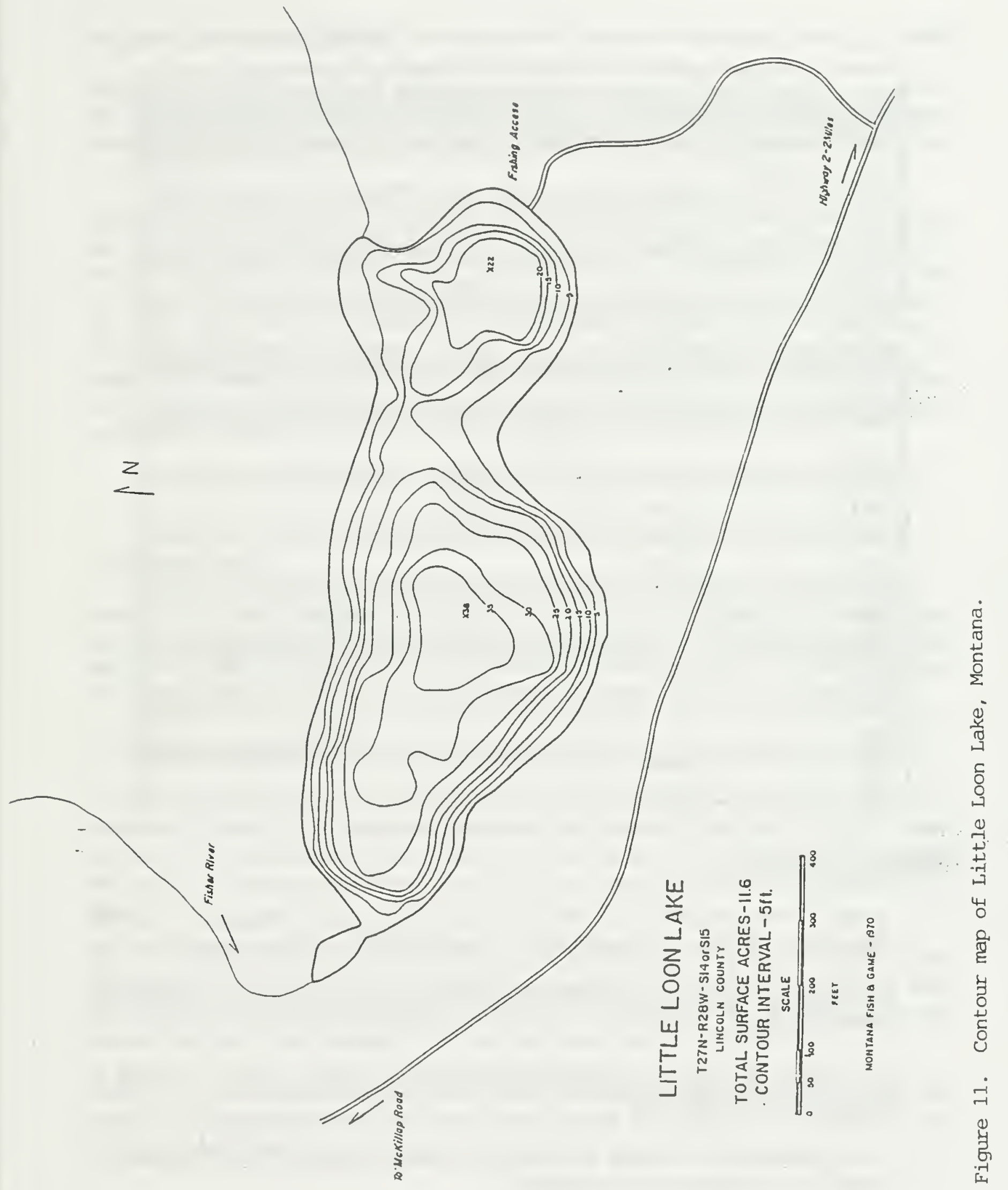


Table 18. Historic planting of Loon and Little Loon Lakes, 1931-1977.

\begin{tabular}{|c|c|c|c|c|c|c|}
\hline \multicolumn{7}{|c|}{ Number of Fish Planted } \\
\hline Year & $\begin{array}{l}\text { Chinook } \\
\text { Salmona }\end{array}$ & $\begin{array}{l}\text { Reninbow } \\
\text { Trout }\end{array}$ & $\begin{array}{l}\text { Brook: } \\
\text { Troot }\end{array}$ & $\begin{array}{l}\text { Arctic } \\
\text { Orayling }\end{array}$ & $\begin{array}{c}\text { Cutthroat } \\
\text { Trout }\end{array}$ & $\begin{array}{l}\text { Samallmoteth } \\
\text { Baps }\end{array}$ \\
\hline 1931 & 15,000 & & & & & \\
\hline 1932 & & 14,000 & . & (2.: & & \\
\hline 1934 & & 52,000 & & & & \\
\hline 1937 & & & 5,000 & 185,000 & & \\
\hline 1938 & & & & 145,000 & & \\
\hline 1940 & $\cdots \cdots$ & 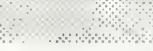 & 2,000 & & & \\
\hline 1941 & & 11,700 & & & & \\
\hline 1944 & & 4,020 & & & & \\
\hline 1945 & & 3,920 & & & & \\
\hline 1946 & & 3,320 & & & & \\
\hline 1948 & & & 4,000 & & & \\
\hline 1950 & & & & & 10,000 & \\
\hline 1953 & & 5,000 & & & & \\
\hline 1954 & & 10,010 & & & $\because$ & \\
\hline 1955 & & 12,650 & & & & \\
\hline 1958 & & & & & 1,200 & \\
\hline 1959 & & & & & 3,200 & \\
\hline 1960 & & & & & 1,040 & \\
\hline 1961 & & & & & 2,000 & \\
\hline 1964 & & & & & I. & 9,000 \\
\hline 1969 & & & & & 4,070 & \\
\hline 1974 & & 20,768 & & & & \\
\hline 1977 & & 8,842 & & & & \\
\hline
\end{tabular}

\section{Management Concerns:}

1. Because of their connection to the Fisher River and Kootenai River drainages, any species planted either authorized or unauthorized, is a potential problem for downstream concerns.

2. Increasing numbers of nongame fish (squawfish, pumpkinseeds) may make maintaining gamefish difficult.

3. The flow-through nature of the system makes it nearly impossible to rotenone the lakes to adequately kill all target fish.

4. A high percentage of warmwater fish (bass, perch) contain parasites in their flesh and this makes them undesirable to many anglers. 


\section{Prefecred Mansgement Option:}

Management options considered included present management with no stocking, attempts to increase bass populations with artificial structure and spawning enhancement, chemical rehabilitation, and supplemental stocking of rainbow trout. Loon and Little Loon lakes received 53 comments.

Under the preferred management option, Loon/Little Loon lakes would be managed for both warm and coldwater species. Through monitoring and adaptive management, rainbow trout may be stocked to supplement the wild population. The source of the trout should be from the spawning run of Loon Lake. Warmwater management would emphasize largemouth and smallmouth bass. This lake system would be included in a comprehensive genetic survey to determine if supplemental stocking is necessary. Additionally, artificial structures may be installed and monitored to determine their effectiveness. The artificial structures would not impede the rainbow trout fishery. Regulations for bass should include spawning restrictions (May 15 through June 30; one bass daily and in possession, 22 inch minimum).

\section{MYRON LAKE}

\section{Lake Description:}

Myron Lake is a small closed-basin lake north of Loon Lake and U.S. Highway 2. The maximum depth of Myron Lake is about 25 feet, and the surface area is approximately 5.5 acres. FWP did not estimate angling pressure for Myron Lake, although it probably supports more than 75 anglers per year.

\section{Lake Management Status:}

Management of Myron Lake commenced in 1973 when an initial gill-net survey produced no fish. In August of that year, 4,080 westslope cutthroat trout were stocked in the lake (Table 19). Since that time, FWP has managed Myron Lake as a low fishing pressure lake. Since 1980, the lake has received trout (species dependent on availability) on a two-year rotation to maximize growth rates.

Myron Lake appears to be one of the very few lakes in the region that was not illegally stocked with undesirable fish species. A gill-net survey conducted in 1994 produced only rainbow trout and westslope cutthroat trout from previous stocking. The catch rate was moderate (2 per net) although the growth and condition of the trout was above average for TCL lakes.

Myron Lake is totally surrounded by Plum Creek Timberlands property that may go up for sale in 1997. A change in ownership and loss of public access would preclude management of this lake for a public fishery. 


\section{Management Concerns:}

1. As with all of the TCL lakes, there is concem that unauthorized introductions of unwanted species might occur.

\section{Preferred Mangagment Option:}

Management options considered included the current management and stocking schedule, consideration for large or trophy trout management, increasing trout stocking rates, or switching to westslope cutthroat plants. Myron Lake received 48 comments.

Under the preferred management option, Myron Lake would be managed as a westslope cutthroat lake. Through monitoring and adaptive management, FWP would adjust stocking rates to maximize catch rates. All activities proposed are provisional on acquiring a permanent access agreement with Plum Creek Timber Company as the lake is entirely within Plum Creek lands.

Table 19. Historic planting of Myron Lake, 1973-1994.

\begin{tabular}{|c|c|c|}
\hline Year & Species Stocked & Number Plinnted \\
\hline 1973 & westslope cutthroat trout & 4,080 \\
\hline 1976 & wests lope cuitthroat trout & 3,010 \\
\hline 1978 & westslope cutthroat trout & 3,000 \\
\hline 1979 & wedtslope cuithroet trout & 1,000 \\
\hline 1980 & wests lope cutthroat trout & 1,007 \\
\hline 1981 & westslope cutthroat trout & 1,008 \\
\hline 1983 & rainbow trout & 1,028 \\
\hline 1985 & rainibaw troit & 1,503 \\
\hline 1987 & rainbow trout & 1,001 \\
\hline 1989 & westalopo cutthront trout & 1,485 \\
\hline 1990 & rainbow trout & 1,512 \\
\hline 1992 & nimbow trout & 1,500 \\
\hline 1994 & westslope cutthroat trout & 1,500 \\
\hline
\end{tabular}

\section{BANANA LAKE}

\section{Lake Description:}

Banana Lake is a small closed-basin lake north of Horseshoe Lake and U.S. Highway 2. The maximum depth of Banana Lake is 17 feet, mean depth is 10 feet, and surface area is 11.5 acres. Between March 1, 1993 and February 28, 1994, FWP estimated that as many as 41 anglers, of which 100 percent were Montana residents, fished at Banana Lake (Montana Statewide Angling Pressure Report).

Lake Management Status: 
No official records exist for Banana Lake prior to 1988. In 1988, Banana Lake was gillnetted to identify species constituency and angling opportunities. Species composition in the lake consisted of longnose suckers, northern squawfish, and pumpkinseeds from unauthorized plants. FWP chemically rehabilitated the lake with rotenone in the fall of 1988 and in 1989 planted the lake with rainbow trout.

A gill-net survey in 1992 indicated that the rehabilitation was a success (no targeted nongame species were found) and rainbow trout planted in 1989 showed good growth and condition. Banana Lake was surveyed again in 1994. Rainbow trout from both 1991 and 1993 plants were caught in the nets and both showed above average growth and conditions. Currently FWP manages the lake for plants of rainbow trout on a two-year rotating basis to maximize growth.

\section{Management Concerns:}

1. As with all chemically rehabilitated lakes, FWP is concerned that unauthorized introductions of unwanted species might occur.

2. It is possible that high flows from the Pleasant Valley Fisher River could overcome the lake and once again give undesirable species access to the lake.

\section{Prefecred Management Option:}

Management options considered included the current management and stocking schedule, consideration as a large or trophy trout lake, increase stocking rates, or switch to westslope cutthroat.

Under the preferred management option, Banana Lake would be managed as a rainbow trout lake with possible additions of westslope cutthroat. Through monitoring and adaptive management, FWP will adjust stocking rates to maximize catch rates.

\section{LOST LAKE}

\section{Lake Description:}

Lost Lake is a small spring fed lake north of Middle Thompson Lake and U.S. Highway 2. The maximum depth of Lost Lake is approximately 20 feet and surface area is 4.5 acres. An intermittent outlet stream (Slimmer Creek) flows to Middle Thompson Lake. FWP did not estimate angling pressure for Lost Lake. 


\section{Lake Management Status:}

No official stocking or gillnetting records exist for Lost Lake prior to 1994. In 1994, Lost Lake was gillnetted to identify species constituency and angling opportunities. Species composition in the lake consisted of brook trout ( 2 per net), longnose suckers (19 per net), and yellow perch (36 per net). The brook trout were small but in good condition. Of the yellow perch caught, only eight percent were eight inches or larger. Brook trout were established either by unscheduled stocking or by illegal introductions; yellow perch are undoubtedly from unauthorized introductions; the longnose suckers are native to the system. Currently, there is no adopted management scheme for this lake.

Lost Lake is physically removed somewhat from the TCL and relatively difficult to access. It does provide an opportunity for a secluded fishing opportunity. Lost Lake is totally surrounded by Plum Creek Timberland property. It is not scheduled for sale at this time. A change in ownership in the future could preclude public access and public fishery management.

\section{Management Concerns:}

High rough fish numbers make successful stocking of trout difficult.

\section{Preferced Management Option:}

Management options considered included no change in management, stocking with trout, or chemical rehab and restock with trout. There were 48 comments on Lost Lake.

Under the preferred management option, Lost Lake would be rehabilitated as funding becomes available and restocked to create a fishery that would include arctic grayling and westslope cutthroat trout. Through monitoring and adaptive management, the fishery would be evaluated and stocking rates adjusted to balance catch rates with preferred size of fish. All activities proposed are provisional on acquiring a permanent access agreement with Plum Creek Timber Company as the lake is entirely within Plum Creek lands. 

